University of South Florida

DIGITAL COMMONS @ UNIVERSITY OF SOUTH FLORIDA
Digital Commons @ University of South Florida

$10-1-2013$

\title{
Project UCARE: Uniform Commuter Assistance Reporting and Evaluation for TDM Programs
}

CUTR

Follow this and additional works at: https://digitalcommons.usf.edu/cutr_nctr

\section{Recommended Citation}

"Project UCARE: Uniform Commuter Assistance Reporting and Evaluation for TDM Programs," National Center for Transit Research (NCTR) Report No. CUTR-NCTR-RR-2010-06, Center for Urban Transportation Research, University of South Florida, 2013.

DOI: https://doi.org/10.5038/CUTR-NCTR-RR-2010-06

Available at: https://scholarcommons.usf.edu/cutr_nctr/96

This Technical Report is brought to you for free and open access by the National Center for Transit Research (NCTR) Archive (2000-2020) at Digital Commons @ University of South Florida. It has been accepted for inclusion in Research Reports by an authorized administrator of Digital Commons @ University of South Florida. For more information, please contact digitalcommons@usf.edu. 

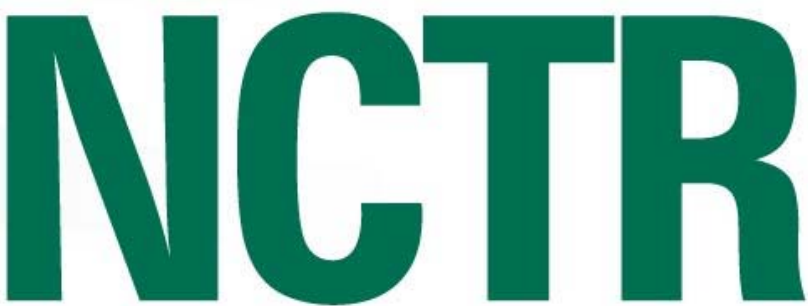

NATIONAL CENTER for TRANSIT RESEARCH

\section{Project UCARE: \\ Uniform Commuter Assistance Reporting and Evaluation for Transportation Demand Management Programs}

FI NAL REPORT September 2013

PROJ ECT NO.

BDK85 977-22

PREPARED FOR

Florida Department of Transportation

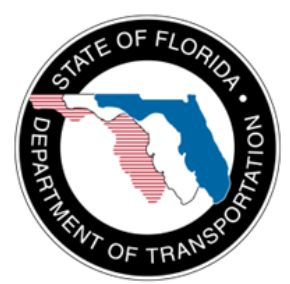




\title{
Project UCARE: Uniform Commuter Assistance Reporting and Evaluation for Transportation Demand Management Programs
}

\author{
BDK85 977-22
}

Prepared for:

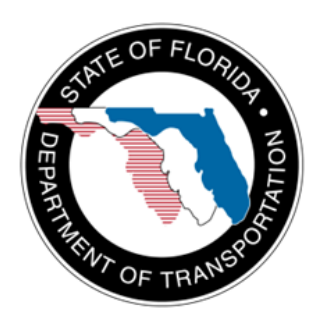

Florida Department of Transportation Michael D. Wright, Project Manager

Prepared by:

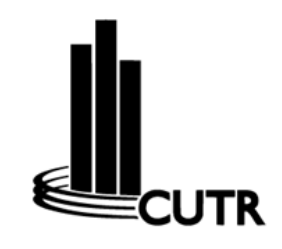

USF Center for Urban Transportation Research

Philip L. Winters, Director, TDM Program

Sara J. Hendricks, Senior Research Associate

Sisinnio Concas, Ph.D., Senior Research Associate

\section{Final Report}

September 2013 


\section{Disclaimer}

The contents of this report reflect the views of the authors, who are responsible for the facts and the accuracy of the information presented herein. This document is disseminated under the sponsorship of the United States Department of Transportation University Transportation Centers Program and the Florida Department of Transportation, in the interest of information exchange. The U.S. Department of Transportation and the Florida Department of Transportation assume no liability for the contents or use thereof.

The opinions, findings, and conclusions expressed in this publication are those of the authors and not necessarily those of the State of Florida Department of Transportation (FDOT). 


\section{Metric Conversion}

\begin{tabular}{|c|c|c|c|c|}
\hline SYMBOL & WHEN YOU KNOW & MULTI PLY BY & TO FIND & SYMBOL \\
\hline \multicolumn{5}{|c|}{ LENGTH } \\
\hline in & inches & 25.4 & millimeters & $\mathrm{mm}$ \\
\hline $\mathbf{f t}$ & feet & 0.305 & meters & $\mathrm{m}$ \\
\hline yd & yards & 0.914 & meters & $\mathrm{m}$ \\
\hline mi & miles & 1.61 & kilometers & $\mathrm{km}$ \\
\hline \multicolumn{5}{|c|}{ VOLUME } \\
\hline fl oz & fluid ounces & 29.57 & milliliters & $\mathrm{mL}$ \\
\hline gal & gallons & 3.785 & liters & L \\
\hline $\mathrm{ft}^{3}$ & cubic feet & 0.028 & cubic meters & $\mathrm{m}^{3}$ \\
\hline$y d^{3}$ & cubic yards & 0.765 & cubic meters & $\mathrm{m}^{3}$ \\
\hline \multicolumn{5}{|c|}{ NOTE: volumes greater than $1000 \mathrm{~L}$ shall be shown in $\mathrm{m}^{3}$} \\
\hline \multicolumn{5}{|c|}{ MASS } \\
\hline $\mathbf{o z}$ & ounces & 28.35 & grams & $\mathrm{g}$ \\
\hline lb & pounds & 0.454 & kilograms & $\mathrm{kg}$ \\
\hline $\mathbf{T}$ & short tons (2000 lb) & 0.907 & $\begin{array}{c}\text { megagrams } \\
\text { (or "metric ton") }\end{array}$ & $M g$ (or "t") \\
\hline \multicolumn{5}{|c|}{ TEMPERATURE (exact degrees) } \\
\hline${ }^{\circ} \mathbf{F}$ & Fahrenheit & $\begin{array}{c}5(F-32) / 9 \\
\text { or }(F-32) / 1.8\end{array}$ & Celsius & ${ }^{\circ} \mathrm{C}$ \\
\hline
\end{tabular}




\section{NCTR Technical Report Documentation}

\begin{tabular}{|c|c|c|c|}
\hline \multicolumn{3}{|c|}{ 2. Government Accession No. } & 3. Recipient's Catalog No. \\
\hline \multicolumn{2}{|c|}{$\begin{array}{l}\text { Project UCARE: Uniform Commuter Assistance Reporting and } \\
\text { Evaluation for Transportation Demand Management Programs }\end{array}$} & \multicolumn{2}{|l|}{ September 2013} \\
\hline \multicolumn{4}{|c|}{ 6. Performing Organization Code } \\
\hline \multicolumn{2}{|c|}{ Philip L. Winters, Sara J. Hendricks, and Sisinnio Concas } & \multicolumn{2}{|c|}{$\begin{array}{l}\text { NCTR 21177922/BDK } 85 \text { 977-22 } \\
\text { USDOT DTRS98-G-0032 }\end{array}$} \\
\hline \multicolumn{2}{|c|}{$\begin{array}{l}\text { 9. Performing Organization Name and Address } \\
\text { National Center for Transit Research } \\
\text { Center for Urban Transportation Research } \\
\text { University of South Florida } \\
4202 \text { East Fowler Avenue, CUT100, Tampa, FL 33620-5375 }\end{array}$} & \multicolumn{2}{|c|}{ 10. Work Unit No. (TRAIS) } \\
\hline \multicolumn{4}{|l|}{$\begin{array}{l}\text { 11. Contract or Grant No. } \\
\text { FDOT BD DTRT07-G-0059 }\end{array}$} \\
\hline \multicolumn{2}{|c|}{$\begin{array}{l}\text { Research and Innovative Technology Administration } \\
\text { U.S. Department of Transportation } \\
\text { Mail Code RDT-30 } \\
1200 \text { New Jersey Ave, SE, Room E33 } \\
\text { Washington, DC } 20590-0001\end{array}$} & \multicolumn{2}{|c|}{$\begin{array}{l}\text { 13. Type of Report and Period Covered } \\
\text { Final Report } \\
\text { March 4, } 2010 \text { - September 30, } 2013\end{array}$} \\
\hline \multicolumn{4}{|c|}{ 14. Sponsoring Agency Code } \\
\hline \multicolumn{4}{|l|}{ 15. Supplementary Notes } \\
\hline \multicolumn{4}{|c|}{$\begin{array}{l}\text { Moving Ahead for Progress in the 21st Century Act (MAP-21) places emphasis upon results and better management of } \\
\text { programs for effective and efficient service delivery. With an increased focus on measuring performance, the } \\
\text { transportation demand management (TDM) industry lags other areas of transportation. Without consistent methods of } \\
\text { evaluating performance and calculating those benefits, the TDM community is at a distinct disadvantage when } \\
\text { transportation investments are being considered at the local, state, and federal levels. This project sought to develop } \\
\text { an accurate and sustainable online system to record data and use a consistent and defensible method for calculating } \\
\text { the impacts of TDM programs. A literature review and a survey of TDM professionals were used to identify the key } \\
\text { outputs and outcomes used today by commuter assistance programs. The data collection tool was pilot tested. The } \\
\text { data from the survey are inputs into the standardized societal benefit estimation procedures contained in FDOT's } \\
\text { TRIMMS }{ }^{\text {TM }} \text { (Trip Reduction Impacts of Mobility Management Strategies) model. To facilitate participation and ease of } \\
\text { use, the final product, UCARE.TRIMMS, was made an online application. }\end{array}$} \\
\hline \multicolumn{2}{|c|}{$\begin{array}{l}\text { 17. Key Words } \\
\text { Transportation demand management, evaluation, societal } \\
\text { benefits }\end{array}$} & \multicolumn{2}{|c|}{ 18. Distribution Statement } \\
\hline $\begin{array}{l}\text { 19. Security Classification } \\
\text { (of this report) } \\
\text { Unclassified }\end{array}$ & $\begin{array}{l}\text { 20. Security Classification } \\
\text { (of this page) } \\
\text { Unclassified }\end{array}$ & $\begin{array}{l}\text { 21. No. of Pages } \\
73\end{array}$ & 22. Price \\
\hline
\end{tabular}




\section{Executive Summary}

Moving Ahead for Progress in the 21st Century Act (MAP-21) became law in 2012; in it national goals are identified, including traffic congestion reduction. The new law charges the United States Department of Transportation (USDOT) to establish metrics by which to evaluate performance toward achieving goals. Measuring performance places new emphasis upon results and better management of programs for effective and efficient service delivery.

With an increased focus on measuring performance, the transportation demand management (TDM) industry lags other areas of transportation. TDM industry faces the lack of an agreed-upon set of performance measures and standard data collection procedures. The industry also lacks a consistent method for calculating a wide range of the societal benefits or outcomes from their efforts. Without consistent methods of evaluating performance and calculating those benefits, the TDM community is at a distinct disadvantage when transportation investments are being considered at the local, state, and federal levels.

This project sought to develop an accurate and sustainable online system to record data and use a consistent and defensible method for calculating the impacts of TDM programs. One of the challenges was to design the system to address TDM programs at different scales (e.g., employer to regional) and small budgets. Another challenge was to foster voluntary use, as the TDM programs are not supported by the mandates as are other modes, such as the National Transit Database for public transportation entities receiving federal funds.

A literature review and a survey of TDM professionals were used to identify the key outputs and outcomes used today by commuter assistance programs (CAP). As part of another project, a pilot test of the data collection instrument was used to collect data from over 1,500 commuters from six Florida regional commuter assistance programs. The survey was administered as a mixed mode methodology to minimize data collection costs. The lessons learned from the CAP evaluation effort resulted in a shift in approach to use the data from the survey as inputs into the standardized societal benefit estimation procedures contained in FDOT'S TRIMMS ${ }^{\mathrm{TM}}$ (Trip Reduction Impacts of Mobility Management Strategies) model. To facilitate participation and ease of use, the final product, UCARE.TRIMMS, was made an online application. 


\section{Table of Contents}

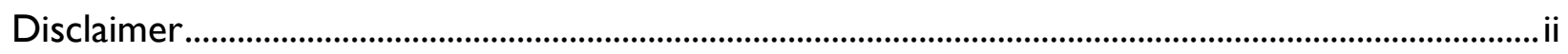

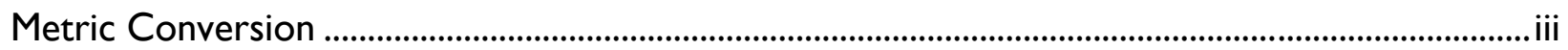

NCTR Technical Report Documentation...........................................................................................

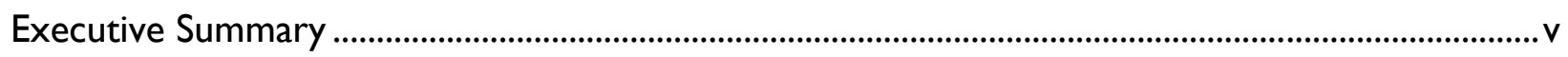

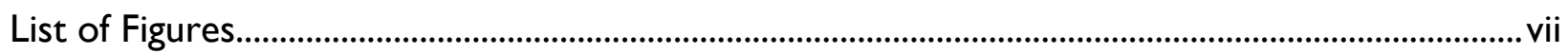

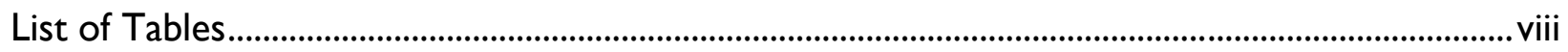

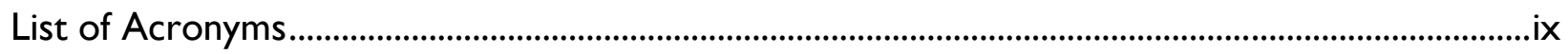

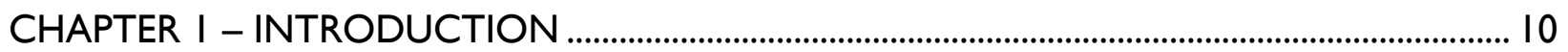

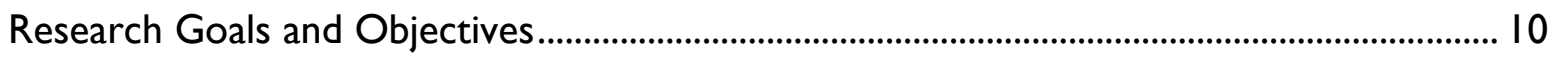

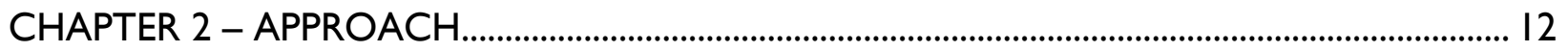

CHAPTER 3 - LITERATURE REVIEW AND SURVEY ............................................................. I4



State-Level Performance Measurement Nationwide............................................................. I4

Multimodal Performance Measurement ........................................................................................ I4

2009 Transportation Management Association Survey ….......................................................... 15

Florida Commuter Assistance Program Evaluation ................................................................ 16

Regional Commuter Assistance Programs Nationwide............................................................ I 17

National Transit Database .................................................................................................... 18

Transit Performance Measurement, Peer Comparisons, and Benchmarking ......................... 19

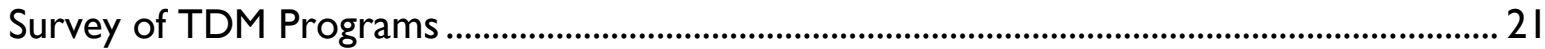

CHAPTER 4 - PILOT TEST OF DATA COLLECTION TOOL ..................................................... 30

CHAPTER 5 - UCARE.TRIMMS SYSTEM AND CONCLUSIONS ................................................. 40

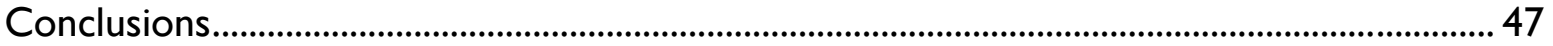

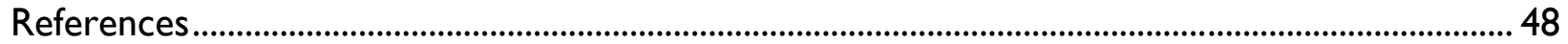

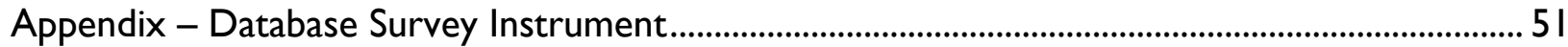




\section{List of Figures}

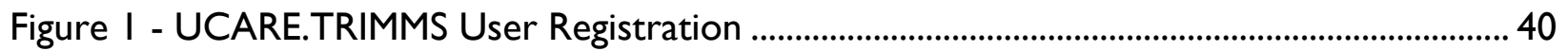

Figure 2 - UCARE.TRIMMS Login Screen ....................................................................................... 4 I

Figure 3 - Program Description........................................................................................................... 4 I

Figure 4 - Employee Survey Results - Baseline................................................................................... 42

Figure 5 - Employee Survey Results - After ……………………………………………………...... 43

Figure 6 - UCARE.TRIMMS Outcomes .......................................................................................... 44

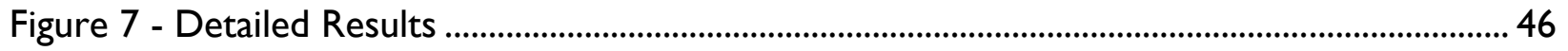




\section{List of Tables}

Table I - Travel Demand Measures of System Utilization ................................................................ 15

Table 2 - Services Most Commonly Offered by TMAs to Their Memberships ................................ 15

Table 3 - Performance Measures (PM) Used by TMAs......................................................................... 16

Table 4 - Respondents by Organizational type …………………………………………………….... 21

Table 5 Service Area of Respondents................................................................................................. 22

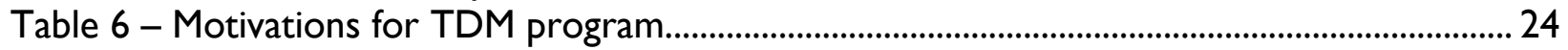

Table 7 - Share of Respondents by Output Type ..................................................................................2 26

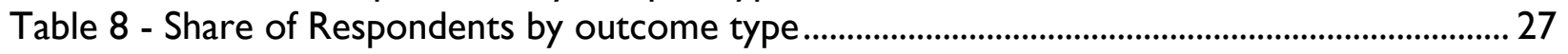

Table 9 - Perceived Benefits of TDM ………………………………………………………………....... 29

Table 10 - Perceived Barriers to TDM Evaluation .................................................................................... 29

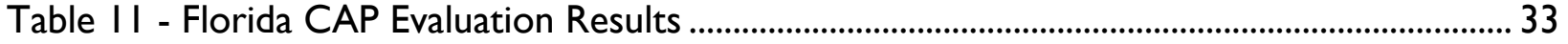

Table 12 - Contacts and Completions for Customer Database Surveys........................................... 39 


\section{List of Acronyms}

$\begin{array}{ll}\text { ACS } & \text { American Community Survey } \\ \text { CAP } & \text { Commuter Assistance Program } \\ \text { CATI } & \text { Computer-Assisted Telephone Interviewing } \\ \text { CUTR } & \text { Center for Urban Transportation Research } \\ \text { ERH } & \text { Emergency Ride Home } \\ \text { FDOT } & \text { Florida Department of Transportation } \\ \text { GHG } & \text { Greenhouse Gases } \\ \text { MAP-2I } & \text { Moving Ahead for Progress in the 2Ist Century Act } \\ \text { NTD } & \text { National Transit Database } \\ \text { PMT } & \text { Person-Miles Traveled } \\ \text { PPPT } & \text { Peak-Period Person Throughput } \\ \text { PUMS } & \text { Public Use Microsample } \\ \text { TDM } & \text { Transportation Demand Management } \\ \text { TRIMMS } & \text { Trip Reduction Impacts of Mobility Management Strategies } \\ \text { VMT } & \text { Vehicle-Miles Traveled }\end{array}$




\section{CHAPTER 1 - I NTRODUCTION}

In response to fiscal constraints and economic recession, government departments at all levels are focused on providing better public services with fewer funds. At the federal level, the new transportation reauthorization, Moving Ahead for Progress in the $21^{\text {st }}$ Century Act (MAP-21), became law in 2012, in which national goals are identified, including traffic congestion reduction. The new law charges the USDOT to establish metrics by which to evaluate performance toward achieving goals. Measuring performance places new emphasis upon results and better management of programs for effective and efficient service delivery.

The federal government has solicited input from the public as it prepares guidance for implementing MAP-21. The major preferences expressed in the National Online Dialogue results reflected strong interest in including measures that focus on movement of people, and not just vehicles to account for multiple modes of travel such as carpooling. There also was the prevailing notion that the performance measures and data collection methods will need to evolve over time to reflect the needs of different areas, introduction of technology, and refinement of the measures themselves to permit scalability for corridors and regions. These considerations were endorsed by the leading transportation demand management (TDM) industry group, the Association for Commuter Transportation (ACT) (ACT, 2012) following numerous discussions and work sessions to develop a set of recommendations for TDM performance measures.

ACT and others recognized a substantial information gap at the local, state, and federal levels about other modes (e.g., carpools) and other programs that could reduce vehicle trips and vehicle miles of travel (e.g., telework, compressed work-week programs). Except for the vanpool element in the National Transit Database (NTD), there also is no single NTD-like database or other management system that regularly collects data to assess performance of commuter assistance program (CAPs). With growing interest in better managing demand in the face of dwindling transportation resources and rising concerns over greenhouse gas emissions (GHG) and traffic congestion, the private and public sectors have recognized the importance of timely and accurate data in assessing the continued progress of all strategies to manage travel demand.

\section{Research Goals and Objectives}

This research project comes at an important time to provide reliable information about performance measurement and to provide recommendations for initiating the development of a systematic and standardized approach to measuring results of TDM programs. The goals of the project are the following.

- Provide an accurate and sustainable system to record data and calculate impacts of TDM programs

- Provide consistency to enable comparisons across programs

- Define peer systems at different scales (program, regional, state, national) to develop benchmarks for comparison

- Establish baseline performance for later comparison

- Identify ways to improve TDM programs 
- Aid in prioritizing program elements for funding

The objective of the UCARE project is to develop a candidate voluntary reporting system that can be eventually implemented on an industry-wide basis.

Chapter 2 provides a description of the approach followed. Chapter 3 summarizes the results of the literature review and survey of TDM professionals. Chapter 4 highlights the lessons learned from piloting the data collection questionnaire. Chapter 5 discusses the final product that integrates data inputs into a new online societal benefit calculation tool. 


\section{CHAPTER 2 - APPROACH}

Following a review of the literature, a survey of transportation demand management (TDM) professionals, and a pilot test of the data collection tools, the key information requirements of a candidate reporting system were identified. The review focused on performance measures and other performance measurement systems, including the requirements of the National Transit Database. The survey of TDM professionals identified the key outputs and outcomes used today by commuter assistance programs. The pilot testing of the survey instrument demonstrated the use of the mixed mode methodology and challenges faced with measuring the effectiveness of ridematching, the most basic service of most commuter assistance programs (CAPs). The pilot survey evaluated the mode-switching performance of Florida at six CAPs from small urban areas like Pensacola to large metropolitan areas such as Miami-Ft. Lauderdale metropolitan statistical area (Hillsman \& Winters, 2012).

As a result of the findings from this field test, the initial concept for the content of the UCARE reporting system was revised. The complexity and costs associated with the data collection meant CAPs would find ease of analysis as an important value of the system. This is especially important as unlike NTD, this system must rely on voluntary compliance if the vision of a standardized approach with a centralized repository were to be realized.

Furthermore, the standardized approach needed to allow for the use of local factors (e.g., emission rates). Consistent and transparent methodologies are also needed for estimating a wide range of the most common outcomes. The lessons learned from the CAP evaluation effort resulted in a shift in approach from financial reporting (ultimately considered too burdensome for a voluntary participation effort like TDM evaluation). The decision was made to integrate with evaluation procedures used by FDOT'S TRIMMS ${ }^{\mathrm{TM}}$ (Trip Reduction Impacts of Mobility Management Strategies) spreadsheet tool. TRIMMS ${ }^{\mathrm{TM}}$ is a spreadsheetbased application designed to evaluate the benefits and costs of transportation demand management initiatives, as they relate to reductions in traffic congestion, air pollution, fuel consumption, global climate change, health and safety impacts, and noise pollution. To make TRIMMS ${ }^{\mathrm{TM}}$ model's benefit estimation methodologies more accessible, the estimation methods were moved online. This approach provides a comprehensive set of societal benefits resulting from the changes in behavior captured from the surveys. This UCARE.TRIMMS hybrid approach allows CAPs to input mode split information obtained from the data collection tools to estimate the key outcomes. These outcomes include changes in emissions, vehicle miles of travel and vehicle trips.

The decision to use benefit estimation procedures contained in TRIMMS was partially based on evidence of its growing credibility and usage within the transportation community. For example, TRIMMS ${ }^{\mathrm{TM}}$ was one of 12 existing benefit-cost tools and methods identified by FHWA in its Operations Benefit/Cost Analysis Desk Reference. (Sallman et al., 2012). FHWA's Congestion Management Process (CMP) Guidebook also lists TRIMMS ${ }^{\mathrm{TM}}$ as one of the tools available to assess congestion management strategies: (Grant et al., 2011). The Environmental Protection Agency (EPA) Office of Transportation Air and Quality (OTAQ) also used TRIMMS ${ }^{T M}$ to conduct a comprehensive study to provide support for national policylevel assessments of transportation control measures (TCM) listed in the Clean Air Act and other strategies, such as road pricing and smart growth, to reduce emissions and vehicle 
miles of travel (VMT). The OTAQ analysis employed TRIMMS ${ }^{\mathrm{TM}}$ to estimate the national potential reductions in VMT under a variety of scenarios through the period 2010-2050: (ICF International, 2011). The San Diego Association of Governments' Integrating Transportation Demand Management Into the Planning and Development Process - A Reference for Cities identified TRIMMS ${ }^{\mathrm{TM}}$ as a applicable sketch-planning model: (HNTB, 2012)

This approach should facilitate the ease of participation and increase the value received by participants. The notation of this system going forward will be "UCARE.TRIMMS". Ideally, this UCARE.TRIMMS data would become the primary source of comparative TDM information for program managers, researchers, and government officials as well as funding agencies. 


\section{CHAPTER 3 - LITERATURE REVIEW AND SURVEY}

This chapter summarizes the review of the literature and the results of the survey of TDM professionals.

\section{Literature Review}

\section{State-Level Performance Measurement Nationwide}

Even prior to the passage of MAP-21, transportation performance measurement has been of interest to state DOTs nationwide for some time. However, a report by the General Accounting Office (GAO) found that if state DOT's used performance measures to inform statewide transportation planning, then the performance measures were most often regarding safety and asset management and less often regarding mobility, congestion, energy consumption, and emissions. Statewide planning and project selection was influenced more by funding availability, governor's priorities, public support and political support, in that order, rather than economic analysis of costs/benefits (GAO, 2010). Additionally, challenges of state DOTs in using performance measures were identified. These included how to define performance measures for qualitative goals such as livability, collecting data, and securing resources to develop and maintain a performance management system, and applying performance terms and methods uniformly. These challenges also included having the staff expertise to use performance data, coordinating data collection activities across the state, and identifying indicators of system performance across multiple modes (GAO, 2010).

\section{Multimodal Performance Measurement}

With the passage of the Community Planning Act in Florida in 2011, a shift has occurred in comprehensive planning that now places emphasis upon the planning and development of multimodal transportation systems in communities. Recent research by the University of Florida identified a range of transportation performance measures to support multimodal growth management and transportation impact analysis (Elefteriadou et al., 2012). The research laid out a procedure for selecting performance measures based upon a community's goals, analysis capabilities and resources. A classification system was developed describing performance measures by five mobility dimensions, including measures of infrastructure and environment, measures of demand and system utilization, measures of user perception, measures of safety, and measures of sustainability (p. 115). In this classification system, measures of interest to commuter assistance programs fall within the category of travel demand as part of the mobility dimension that measures demand and system utilization. Performance measures for travel demand were identified. Table 1 lists travel demand measures of system utilization, divided in two categories of trip generation measures and mode share measures. 
Table 1- Travel Demand Measures of System Utilization

\begin{tabular}{|l|l|}
\hline Trip Generation & Measure \\
& Average vehicle occupancy \\
& Bicycle and pedestrian activity \\
& Community capture \\
& Internal capture \\
& Mean daily trips per household \\
& Mean daily vehicle trips per household \\
& Person miles traveled (PMT) \\
& Person trips \\
& Trip length by mode \\
& Vehicle miles of travel (VMT) (by mode) \\
& VMT per capital \\
\hline Mode Share & Bicycle and pedestrian mode share \\
& Mode choice availability \\
& Mode split \\
& Safe Routes to School (SRTS) Program effectiveness \\
& Single occupant vehicle (SOV) mode split \\
\hline & et al. 2012, Table A.16, P. 127.
\end{tabular}

Source: Elefteriadou et al. 2012, Table A.16, p. 127.

\section{Transportation Management Association Survey}

Similarly to CAPs, transportation management associations (TMA) are often formed for the purpose of addressing traffic congestion problems, though often with a geographic focus smaller than a region. TMAs also may provide some of the same services that regional commuter services programs provide. TMA activities have been periodically evaluated nationwide since 1993. The most recent survey of TMAs in the U.S., conducted in 2009, included questions regarding services offered, as well as measurement and evaluation of organization activities (Killeen et al. 2010). Survey results showed that TMAs offer a wide array of services. Table 2 lists the five most commonly offered services by TMAs to their memberships, in order from highest to lowest percentages of TMAs who offer the services. Forty percent of TMA Survey respondents indicated that their TMAs offer rideshare matching.

Table 2 - Services Most Commonly Offered by TMAs to Their Memberships

\begin{tabular}{|l|l|}
\hline $\begin{array}{l}\text { \% TMA Survey Respondents that } \\
\text { Offer Service }\end{array}$ & \\
\hline 47 & Promotional/marketing materials \\
\hline 45 & Employer travel surveys \\
\hline 44 & Promotional events \\
\hline 44 & Trip reduction plans/travel plan development \\
\hline 40 & Rideshare matching \\
\hline
\end{tabular}

Source: Killeen et al. 2010, Fig. 31. 
Each TMA may offer a different combination of services from other TMAs. TMAs also may allocate differing proportions of program resources to each service provided. The following is a list of examples of other services that may be offered by TMAs (Killeen et al., 2010).

- Email newsletters

- Guaranteed ride home

- Advocacy

- ETC training

- Cycling program assistance

- Transit pass sales

- Employer networking events

- Parking management planning

- Web-based travel information

- Site design assistance

- Relocation services

- Tax benefit program assistance

- Ridesharing incentives
- Personalized journey planning

- Telework program assistance

- Subsidized transit passes

- Vanpool services

- Real-time travel alerts

- Shuttle/transit provision

- Social media communications

- Vanpool subsidies

- Web-based mapping

- Sample workplace policies

- Carshare programs

- Freight delivery plans

TMA Survey respondents were also asked how their TMAs measure success. Table 3 lists performance measures used by TMAs, ranked in order from highest to lowest percentages of TMAs that use the performance measures. Tracking employment site-level mode shift was cited by 45 percent of TMA Survey respondents. This was the most commonly used performance measure.

Table 3 - Performance Measures (PM) Used by TMAs

\begin{tabular}{|c|l|}
\hline $\begin{array}{l}\text { \% TMA Survey } \\
\text { Respondents } \\
\text { that Use PM }\end{array}$ & Performance Measures \\
\hline 45 & Mode shift at the work place or site level \\
\hline 44 & Mode shift at the TMA-wide level \\
\hline 38 & Number of new ride match database registrations \\
\hline 38 & Organizational member satisfaction with TMA services \\
\hline 36 & Utilization rates (vanpools in operation, carpool trips logged) \\
\hline 32 & Traveler awareness of TMA programs and services \\
\hline 24 & TMA cost per unit of pollution reduction \\
\hline 22 & TMA cost per trip reduced \\
\hline 22 & TMA cost per vehicle mile/kilometer reduced \\
\hline 19 & Mode share of TMA member organization compared to control group \\
\hline
\end{tabular}

Source: Killeen et al. 2010 Fig. 33

\section{Florida Commuter Assistance Program Evaluation}

The Florida Commuter Assistance Program (FLCAP) of the Florida Department of Transportation (FDOT) Public Transit Office has historically emphasized program monitoring 
and evaluation to aid in the continual improvement of transportation management organizations (TMO) and CAPs throughout the state. FLCAP has developed and maintained program procedures that established common evaluation measure definitions, and survey and reporting guidance (FDOT, 2002).

In October 2012, an evaluation of the regional commuter assistance programs (CAP) in Florida was completed. The project was the first statewide review of the carpool/vanpool formation activities of six Florida commuter services programs in six of the seven districts (Hillsman and Winters, 2012). The study applied similar definitions, methods and calculations to the evaluation of all CAPs. The study collected data from the CAPs on several key performance measures previously identified (CUTR, 2008). The collection procedure included the conduct of two surveys, one was of a representative sample of the general population and the second survey was of a representative sample of persons who were registered with a CAP program to receive services. The data collected resulted in the calculation of the following key performance measures.

- Vehicle miles of travel reduced

- Vehicle trips reduced

- Percent of drive-alone customers switching to a commuter alternative

- Annual current carpool and vanpool person miles of travel

- Annual current carpool and vanpool person trips

- Customer round-trip commutes avoided by use of telework

- Customer round-trip commutes avoided by use of Alternative Work Schedules

- Gasoline consumption reduced

- Carbon dioxide

- Carbon footprint $\left(\mathrm{CO}_{2}\right.$ equivalent)

- Cost savings to commuters

- Customer satisfaction

- Share of customers receiving names of potential ridematches who contacted others

- Share of customers receiving names to pool and contacted other who actually formed a pool

- Overall share of customers who were successful in forming a pool with assistance from CAP

\section{Regional Commuter Assistance Programs Nationwide}

Several regional commuter assistance programs nationwide were reviewed for their efforts to evaluate program effectiveness. These included the Georgia Clean Air Campaign (Gray, 2012), Arlington County Commuter Services in Virginia (J ennings, 2012), Triangle J Council of Governments in North Carolina (Center for Transportation and the Environment et al. 2010), MassRIDES serving the State of Massachusetts (MassRIDES, 2010), Valley Metro serving the Metro Phoenix area in Arizona (Westgroup Marketing Research, Inc., 2009), the Metropolitan Washington Council of Governments Commuter Connections program (LDA Consulting et al., 2012), and general transportation performance measurement by the Metropolitan Council and Mn/DOT in the Twin Cities region of Minnesota (Transit for Livable Communities, 2008). The review found that the monitoring and performance evaluation activities among commuter assistance programs differ in numerous ways, including the 
objectives to be evaluated, the menu of commuter services offered, evaluation timeframes, selected performance measures, definitions used, and the types of data collected.

\section{National Transit Database}

The concept for UCARE.TRIMMS draws heavily from the extensive research and activity in the public transit industry to measure performance as a means to identify ways to improve cost effectiveness. One of the first steps to measuring performance is finding a source of reliable data. The National Transit Database (NTD) of the Federal Transit Administration (FTA) is a repository of over 1,000 data elements describing service delivery and costs associated with public transit agencies. These data are used to establish performance measures. Started in 1984, it is based upon the organizing principles described by project FARE (Uniform Financial Accounting and Reporting Elements) (Arthur Andersen \& Co., 19721973). FTA requires all transit agencies that receive Urbanized Area Formula Grant Program (Section 5307) funds must report data to the NTD annually. The data is primarily used to report on safety and economic performance.

The NTD also includes data on vanpools. Providers of vanpool services report annual data to the NTD on service provided and consumed. Providers must report a 100-percent count of annual total unlinked passenger trips (UPT) and an estimate of annual total passenger miles traveled through random sampling meeting minimum 95\% confidence and $10 \%$ precision. For service provided, providers must report a full count of vehicle revenue miles and vehicle revenue hours.

To develop a NTD tool for vanpool services, a research project developed a set of sampling plans for each peer level of vanpool services to collect sample data and estimate system passenger miles (Chu, 2008). To develop this tool, there were several steps.

1. Assemble vanpool service and consumption data for Florida vanpool providers. These data could include a number of vanpool system characteristics, including vehicle ownership, vanpool driver requirements, responsibilities, and incentives, vanpool agency responsibilities, vehicle characteristics, and vanpool fares.

2. Classify vanpool service providers into peer groups.

3. Develop plans for collecting consumption data for each peer group.

4. Develop a 2003 Excel spreadsheet for agencies to sample, record, process, and report vanpool service and consumption data to the NTD. The spreadsheet provides the data in a form to put into NTD Forms FAA-10 (Federal funding allocation), MR-20 (monthly reporting), and S-10 (annual reporting). Forms were developed for collecting service and consumption data for individual vanpools.

Users of the vanpool NTD tool would provide data inputs, including general information, route data, sample data, daily activity data, and operating expenses. Vanpool performance measures available from the National Transit Database include the following:

- Operating expense per passenger mile

- Farebox recovery rate

- Passenger trips per revenue hour 
- Average passenger trip length

- Average passenger fare per trip

- Average passenger fare per mile

- Average subsidy per passenger trip

- Average subsidy per passenger mile

There are some limitations to the NTD, including that the NTD may not contain the most recent one- to two-years of data. There is also some question that not all reporting agencies interpret terms in the same way and there may be resulting reporting inconsistencies. Nevertheless, the NTD is a rich source of comparative data. The UCARE.TRIMMS project considers the NTD as a potential model for a database for commuter assistance programs. Recent research has focused upon using the NTD for performance measurement. The Transit Cooperative Research Program (TCRP) Report 88 made headway in this process.

\section{Transit Performance Measurement, Peer Comparisons, and Benchmarking}

TCRP Report 88 is a guidebook describing the steps for developing a transit performance measurement system (Kittelson \& Associates, Inc. et al., 2003). It discusses the characteristics of an effective performance management system, provides case studies of successful transit programs, and draws from lessons of private industry. It describes measurement tools, and lists various data sources, including the NTD, in-house operations record keeping, U.S. Bureau of the Census demographic information, state and local transportation department traffic data, transportation planning models, and manually collected data, such as ridership counts and customer surveys. It identifies and categorizes more than 400 different transit-related performance measures.

The more recent TCRP Report 141 (Ryus et al., 2010) includes developing performance measures based on uniformly reported data that are transparent, credible and relevant to the performance question of interest. The goal is to enable assessment of transit agencies of different sizes, modes and operating environments. This method emphasizes flexibility in the selection of performance measures related to particular outcomes of interest and does not prescribe a particular set of performance measures. Performance categories can be departmental in nature, such as administration (financial performance), daily operations, such as maintenance and construction, long term policy and planning, and marketing (customer focus and perspective). Alternatively, performance categories could also be specified based upon customer experience as compared to cost, such as service supply/availability, service consumption, quality of service, including travel time, community impact, safety and security, cost efficiency, and operating ratio.

TCRP Report 141 goes a step farther in transit performance measurement to include the different levels of benchmarking as a means to identify ways for a transit agency to improve its service and operations. Based upon common themes from private industry, study authors define benchmarking as "...the process of systematically seeking out best practices to emulate" (p. 6). Benchmarking is important because it recognizes that performance measures alone can provide data but no context and peer comparisons do not answer why differences in performance among similar transit agencies occur. 
With the stages of benchmarking borrowed from the European EQUIP project (University of Newcastle upon Tyne et al., 2000a and 2000b), the levels of benchmarking begin with trend analysis by comparing the performance over time within a single agency. Beyond this, transit agencies may seek best practices by identifying other agencies that are peers. Once these peers are identified, performance measures and trends can be compared and transit agencies may go a step further by contacting these peer agencies to engage in discussion about what causes differences in performance and how best practices of one transit agency can be adapted to another. I ssues with regard to the benchmarking process are reliability of data and comparability. How are differences between agencies overcome so that useful comparisons can be made? TCRP Report 141 proposes a peer-selection process and ways to incorporate policy objectives and other factors into the process. Peer comparisons are not meant to 'rank' agencies but to help agencies assess relative strengths and weaknesses as a starting point in developing strategies to improve performance.

INTDAS, a software tool developed by Florida International University, is the Integrated National Transit Database Analysis System; it is a series of spreadsheets that can be accessed online by transit agencies (Gan, 2010). Housed within the Florida Transit Information System (FTIS), INTDAS automates the peer "likeness" determination process by applying the methods from TCRP 141 to identify transit peers as described by their NTD data and based upon the selected categories of interest of INTDAS users. For example, similarities among peers could be based upon the transit modes operated, agency characteristics that are partially or wholly under transit agency control, service area characteristic, and regional geographic proximity.

The highest level of benchmarking is described by the creation of a network of agencies that voluntarily remain in touch to compare their performance and learn from each other through ongoing activities of communication and exchange. The UCARE.TRIMMS project might lay the foundation for developing a benchmarking process that is tailored to the needs of commuter assistance programs.

In the development of the UCARE.TRIMMS preliminary design criteria, based upon the Financial Accounting and Reporting Elements (FARE) project that developed the NTD, more distinctions between public transit and commuter assistance programs become apparent. Unlike public transit, CAPs are generally not capital intensive with regard to structures, support facilities, and rolling stock. As a result, the cost accounting for transit is highly detailed with regard to capital and equipment whereas CAP capital assets might be very limited and the primary costs are labor. Also, while there is much variation in the type of public transit service provided, such as motor bus, light rail, cable car, jitney, etc., this variety is unified by the fact that all these services provide passenger trips. CAPs do not necessarily provide passenger trips directly, but rather provide support for travel choices by increasing customer awareness, understanding, desire, and know-how to better utilize travel choices. CAPs often promote multiple modes, each of which requires fundamentally different infrastructure and programmatic support. CAPs are usually not in direct control of providing a passenger trip, nor are they in control of the quantity and quality of transit service provided. As a result, the profile of reporting elements for UCARE.TRIMMS will be 
challenged to establish performance metrics that are not only appropriate to the objective and service provided, but that are useful across programs for comparison purposes.

\section{Survey of TDM Programs}

In addition to the literature review, an online survey was distributed to the TDM community via the TRANSP-TDM listserv to provide additional insights into the challenges and opportunities for evaluating TDM programs. Only 47 usable responses were provided but these provide additional confirmation on the variety of needs, desire for context/local conditions, and simplicity.

Table 4 - Respondents by Organizational Type

\begin{tabular}{|l|l|r|r|r|}
\hline \multicolumn{1}{|l|}{ Organization Type } & Frequency & Percent & Valid Percent \\
\hline \multirow{1}{*}{} & Local government agency & 9 & 19.1 & 22.0 \\
\cline { 2 - 5 } & $\begin{array}{l}\text { Metropolitan Planning } \\
\text { Organization/Council of } \\
\text { Governments/Regional }\end{array}$ & 11 & 23.4 & 26.8 \\
\cline { 2 - 5 } & $\begin{array}{l}\text { Non-profit/Not for Profit } \\
\text { agency- but not a TMA }\end{array}$ & 3 & 6.4 & 7.3 \\
\cline { 2 - 5 } & Private company & 2 & 4.3 & 4.9 \\
\cline { 2 - 5 } & State government agency & 1 & 2.1 & 2.4 \\
\cline { 2 - 5 } & Transit agency & 2 & 4.3 & 4.9 \\
\cline { 2 - 5 } & Transportation Management & 9 & 19.1 & 22.0 \\
& Association/Organization & 4 & 8.5 & 9.8 \\
\cline { 2 - 5 } & University & 41 & 87.2 & 100.0 \\
\cline { 2 - 5 } & Total & 6 & 12.8 & \\
\hline Notal & No response & 47 & 100.0 & \\
\hline
\end{tabular}

The following tables represent the 47 organizations that are responsible for the day-to-day management and operations of one or more TDM programs. As expected, the service areas of these programs vary considerably from their own facilities to national in scope. 
Table 5 Service Area of Respondents

\begin{tabular}{|c|c|c|c|}
\hline \multirow[t]{2}{*}{$\begin{array}{l}\text { Which one of the geographies best } \\
\text { describes your TDM PROGRAM } \\
\text { service area? }\end{array}$} & Frequency & Percent & Valid Percent \\
\hline & I & 2.1 & 2.3 \\
\hline $\begin{array}{l}\text { Statewide (or multiple } \\
\text { contiguous states) }\end{array}$ & 3 & 6.4 & 6.8 \\
\hline $\begin{array}{l}\text { Metropolitan Statistical Area } \\
\text { (Skip to Q6) }\end{array}$ & 13 & 27.7 & 29.5 \\
\hline City or County (Skip to Q7) & 16 & 34.0 & 36.4 \\
\hline Central Business District, & 4 & 8.5 & 9.1 \\
\hline Activity Center or Corridor & & & \\
\hline $\begin{array}{l}\text { Only own facilities (i.e., our } \\
\text { own employees) }\end{array}$ & 7 & 14.9 & 15.9 \\
\hline Total & 44 & 93.6 & 100.0 \\
\hline No Response & 3 & 6.4 & \\
\hline Total & 47 & 100.0 & \\
\hline
\end{tabular}

Commensurate with the variety of service areas, the motivations for the existence of the TDM program also vary ( 
Table 6). Reducing emissions and traffic congestion were the major reasons over two-thirds of the respondents. Clearly, the design of the UCARE.TRIMMS system must be designed to help report on their ability to reduce emissions and traffic congestion. 
Table 6 - Motivations for TDM program

\begin{tabular}{|c|c|c|c|c|}
\hline Motivation & $\begin{array}{l}\text { Very Great } \\
\text { Extent }\end{array}$ & $\begin{array}{l}\text { To Some } \\
\text { Extent }\end{array}$ & $\begin{array}{l}\text { A Small } \\
\text { Extent }\end{array}$ & $\begin{array}{l}\text { Not } \\
\text { At All }\end{array}$ \\
\hline Reduce emissions & 69.0 & 23.8 & 7.1 & 0.0 \\
\hline Reduce traffic congestion & 66.7 & 28.6 & 4.8 & 0.0 \\
\hline Reduce parking demand & 52.4 & 23.8 & 19.0 & 4.8 \\
\hline Increase mobility & 50.0 & 42.9 & 4.8 & 2.4 \\
\hline Create more livable communities & 47.6 & 28.6 & 21.4 & 2.4 \\
\hline Increase access to jobs & 45.2 & 35.7 & 2.4 & 16.7 \\
\hline $\begin{array}{l}\text { Respond to customer requests for commute } \\
\text { services }\end{array}$ & 40.5 & 40.5 & 14.3 & 4.8 \\
\hline Reduce energy consumption & 38.1 & 35.7 & 26.2 & 0.0 \\
\hline $\begin{array}{l}\text { Respond to the lack or limits of public transit } \\
\text { service in some areas }\end{array}$ & 31.0 & 33.3 & 21.4 & 14.3 \\
\hline Foster economic development & 28.6 & 38.1 & 11.9 & 21.4 \\
\hline Improve safety & 26.8 & 46.3 & 14.6 & 12.2 \\
\hline $\begin{array}{l}\text { Meet local or state regulations for trip reduction } \\
\text { or growth management }\end{array}$ & 26.8 & 17.1 & 22.0 & 34.1 \\
\hline $\begin{array}{l}\text { Receive positive community } \\
\text { relations/recognition }\end{array}$ & 25.0 & 25.0 & 37.5 & 12.5 \\
\hline $\begin{array}{l}\text { Promote usage of tax benefits for commuter } \\
\text { programs }\end{array}$ & 14.3 & 23.8 & 31.0 & 31.0 \\
\hline $\begin{array}{l}\text { Ensure continuity of operations in the event of a } \\
\text { natural disaster or other disruptive event }\end{array}$ & 2.4 & 12.2 & 34.1 & 51.2 \\
\hline Provide transportation to the disabled & 0.0 & 7.3 & 43.9 & 48.8 \\
\hline Provide transportation to seniors & 0.0 & 4.9 & 29.3 & 65.9 \\
\hline
\end{tabular}

While the motivations for the program should be reflected in how progress is tracked and how success is measured, the survey population was asked to identify the outputs and outcomes used by their program. The term "Output" means a TDM/commuter assistance program (CAP) activity and/or associated product or service related to progress toward the CAP goals and objectives. "Outcome" means the result, effect, or consequence that will occur from carrying out a TDM/commuter assistance program or activity that is related to the program goals and objectives. Outputs, when combined, can create the desired outcomes.

Mode split, reported as single occupant vehicle (SOV) or non-SOV measures, was cited by over 60 percent of the respondents ( 
Table 7). The UCARE.TRIMMS system would need to collect and report on changes in mode split. 
Table 7 - Share of Respondents by Output Type

\begin{tabular}{lc}
\hline Outputs & Percent \\
\hline Alternate mode usage (AMU) or non-Single Occupant Vehicle rate & 63.8 \\
Drive alone/Single Occupant Vehicle (SOV) rate & 61.7 \\
Number of participants in events (e.g., Bike to Work Day) & 59.6 \\
Number of carpool participants & 57.4 \\
Number of bicycle commuters & 53.2 \\
Number of companies participating & 46.8 \\
Level of awareness of program & 46.8 \\
Number of vanpool participants & 42.6 \\
Customer satisfaction & 42.6 \\
Number of transit passengers & 38.3 \\
Number of commuters switching modes & 36.2 \\
Number of emergency ride home registrants & 34.0 \\
Number of commuters requesting assistance & 29.8 \\
Number of vans in service & 29.8 \\
Number of telework participants & 25.5 \\
Number of schools with Safe Routes to School activities & 19.1 \\
Number of employers offering alternative work schedules & 17.0 \\
Vehicle trip rate per employee & 10.6 \\
\hline
\end{tabular}

As indicated earlier, reducing emissions and traffic congestion were reported to be the primary motivations for the existence of the TDM program. The desired outcomes ( 
Table 8) reflect those motivations. Changes in greenhouse gas emissions, gallons of gasoline and vehicle miles of travel were the most frequently cited outcomes. Notably, other outcomes such as mobility, health and safety were also cited by at least one-third of the respondents. To the extent possible, UCARE.TRIMMS should seek to provide estimates of many of these outcomes. 
Table 8 - Share of Respondents by Outcome Type

\section{Outcomes}

Percent

Emissions - e.g., Greenhouse Gases

61.7

Energy - e.g., gallons of gasoline saved

46.8

Vehicle miles of travel (per capita, per person trip, or total)

Parking demand

36.2

Mobility - Passenger trips provided

Extent of congestion - Actual time or percentage of time that traffic on

23.4

freeways and principal arterial streets is flowing at less than free-flow speeds

OR Percentage of travel (vehicle-miles) on freeways and principal arterial streets is flowing at less than free-flow speeds

Health

Livability

Vehicle trips (per capita, per person trip, or total)

Travel time per Trip - The average time required to travel from an origin to a destination on a trip that might include multiple modes of travel

Accessibility

17.0

Safety

Reliability - The amount of additional time that travelers must add to their average trip time in order to be on time $95 \%$ of the time (a.k.a. buffer index)

Safety - fatalities and injuries

Annual Hours of Delay

Person throughput - The number of people per hour that are being

accommodated by a roadway segment

Speed

2.1

Vehicle throughput- The number of vehicles per hour that are being

0.0 accommodated by a roadway segment

Mobility - Passenger trips provided

0.0

Incident delay - The increase in travel time experienced by individuals due to

0.0 incidents

All the respondents recognize benefits from evaluating the TDM program. Over 60 percent of the respondents noted the benefits include providing evidence of diligence to others, justifying future funding requests and supplying factual information for public relations (Table 9). 
Table 9 - Perceived Benefits of TDM

What are the benefits, if any, do you expect to receive from evaluating your TDM PROGRAM?

Shows evidence to management, public agencies, and the public of the diligence and sincerity of the organization

Supplies powerful factual information for public relations

Justifies future funding requests

Redirects efforts when it is determined that elements of the program have or do not have desired results.

Meets a contractual requirement from funder(s)

Designing the evaluation requires the staff to examine the clarity of the

organization's objectives, the ease with which they can be measured, and the possibility of being achieved.

Helps others to anticipate problems in implementing similar programs and provides a "thermometer" against which others may measure their success

No benefits from evaluating the TDM Program

Only one in six reported no barriers to evaluating there TDM program. The comparability and ease of measurement were the barriers most frequently mentioned. The preferred UCARE.TRIMMS system should be adjustable for local conditions to help provide context.

Table 10 - Perceived Barriers to TDM Evaluation

What barriers, if any, do you face with respect to evaluating your TDM PROGRAM? Percent

Lack of context/comparability

Outcomes are too difficult to measure

Cost of evaluation

Lack of technical expertise in designing and conducting the

No time to conduct the evaluation

No barriers for evaluating our TDM program

Lack of credibility of self-evaluations

Funding agency is disinterested in evaluation 


\section{CHAPTER 4 - PILOT TEST OF DATA COLLECTI ON TOOL}

The previous chapter reviewed the literature and summarized the survey results of commuter assistance programs. It described the type of outputs and outcomes used by commuter assistance programs. This chapter summarizes Florida's experience with collecting the data. It highlights the methodology used and challenges encountered to collect such data. Ultimately, the combination of current state of the practice and practical lessons learned shaped the approach to devise an online tool that provides an easy method of collecting the data and providing a consistent but customized approach to evaluating the major outcomes identified by the CAPs.

Several findings from the CAP evaluation provide important considerations to developing UCARE.TRIMMS. First, CAPS were unable to fully allocate costs to the activities being evaluated. One reason is CAPs may be located institutionally within another organization making it difficult to identify the proportion of overhead and administrative costs used by the CAP. Another factor is the CAP may be supported with a mix of in-kind contributions and involved with other services such as Safe Routes to School, shuttle operations, etc.

During the pilot test, researchers discovered CAPs did not collect detailed information from program registrants about their initial travel habits, including initial work schedule, use of multiple modes per day and different travel modes on different days of the week. These data are necessary to establish baseline performance, better characterize the travel patterns and commuter service needs of CAP customers, and more accurately measure incremental but important changes in travel as a result of CAP services (e.g., changes in frequency of mode use).

The Florida CAP evaluation project focused almost exclusively on assessing the impact of the carpool and vanpool services. This was a practical starting point because all the CAPs in Florida provide this basic service and shared common issues. This approach would allow the evaluation of CAP performance by mode, in much the same way NTD data can be sorted and analyzed by mode for trend and peer analysis purposes.

As previously mentioned, each CAP allocates their resources to providing a unique array of services, including Emergency Ride Home, Safe Routes to Schools, shuttle services, and telecommuting assistance to employers. The Florida CAPs neither had an overhead rate nor took steps to fully allocate the costs to each of these program elements, including capturing in-kind costs (e.g., donated office space).

Going forward, future research should expand the performance evaluation to include more types of CAP services. To that end, the UCARE.TRIMMS system should be designed to allow changes easily. To this end, the online version will always provide the latest methods, current rates, etc. As the UCARE.TRIMMS evaluation tool gains more voluntary acceptance by CAPs and then efforts to address the fully allocated cost issues should follow.

There were additional challenges to conducting surveys for gathering performance data. Due to the nature of the customer services provided by CAPs, surveys are one of the best 
evaluation methods for capturing performance results. The CAP evaluation project conducted both a survey of the general population and a separate survey of CAP registered customers. However, the CAP evaluation project found that surveys are becoming increasingly more difficult and expensive to administer, given increasing use by the public of wireless telephone service that requires time-consuming manual entry of phone numbers, voice mail and Caller ID for screening calls, and pager and faxes with unique telephone numbers that makes it less likely to reach a personal phone. Use of email for survey delivery by Internet, while providing a cost-effective alternative for reaching a greater number of participants, also introduces additional issues relating to reaching a random and representative subset of the population, as well as altering participant interpretation of survey questions as compared to survey delivery via telephone conversation.

The following section provides a summary of these challenges to aid parties in conducting the survey to collect the basic data needed for UCARE.TRIMMS.

Beginning with the end in mind, 
Table 11 shows the performance measures in Florida and the statewide results. Appendix A contains the survey instrument used to estimate these results from the customer survey. UCARE.TRIMMS focuses on those measures with an asterisk (*). 
Table 11 - Florida CAP Evaluation Results

\begin{tabular}{|c|c|c|}
\hline \multirow{2}{*}{$\begin{array}{l}\text { Performance Measure } \\
\text { Vehicle miles of travel reduced* }\end{array}$} & \multicolumn{2}{|l|}{ Results } \\
\hline & $28,289,200$ & Miles \\
\hline Vehicle trips reduced* & 847,800 & Trips \\
\hline $\begin{array}{l}\text { Percent of Drive-alone Customers Switching to a } \\
\text { Commute Alternative (the most restrictive definition) }\end{array}$ & $3 \%$ to $16 \%$ & $\begin{array}{l}\text { Net values of } \\
\text { customers }\end{array}$ \\
\hline $\begin{array}{l}\text { Percent of Drive-alone Customers Switching to a } \\
\text { Commute Alternative (a more generous definition) }\end{array}$ & $13 \%$ to $35 \%$ & $\begin{array}{l}\text { Gross values } \\
\text { for all } \\
\text { customers } \\
\text { influenced by } \\
\text { program }\end{array}$ \\
\hline $\begin{array}{l}\text { Annual current carpool and vanpool person miles of } \\
\text { travel* }\end{array}$ & $35,152,948$ & Person Miles \\
\hline Annual current carpool and vanpool person trips* & $1,145,385$ & Person Trips \\
\hline $\begin{array}{l}\text { Customer Round-Trip Commutes Avoided By Use of } \\
\text { Telework }\end{array}$ & 601,061 & Trips \\
\hline $\begin{array}{l}\text { Customer Round-Trip Commutes Avoided By Use of } \\
\text { Alternative Work Schedules }\end{array}$ & 721,537 & Trips \\
\hline Gasoline consumption reduced* & $1,243,400$ & gallons \\
\hline Carbon Dioxide* & 11,050 & Metric tons \\
\hline Carbon Footprint (CO2 Equivalent)* & 11,390 & Metric tons \\
\hline $\begin{array}{l}\text { Cost Savings to Commuters * } \\
\text { (saving based on only fuel, tire, maintenance and } \\
\text { reduced depreciation costs) }\end{array}$ & $\$ 9,847,000$ & Per year \\
\hline $\begin{array}{l}\text { Customer Satisfaction } \\
(1=\text { Not At All Satisfied and } 10=\text { Very Satisfied })\end{array}$ & 5.6 to 7.2 & \\
\hline Customer Satisfaction - Would Recommend & \multicolumn{2}{|c|}{$\begin{array}{l}\text { Depending on the CAP: } 54 \text { to } 84 \\
\text { percent would definitely or } \\
\text { probably recommend }\end{array}$} \\
\hline $\begin{array}{l}\text { Share of customers receiving names of potential } \\
\text { ridematches who contacted others }\end{array}$ & $37 \%$ & \\
\hline $\begin{array}{l}\text { Share of customers receiving names to pool and } \\
\text { contacted other who actually formed a pool }\end{array}$ & $45 \%$ & \\
\hline $\begin{array}{l}\text { Overall share of customers who were successful in } \\
\text { forming a pool with assistance of CAP }\end{array}$ & $8 \%$ & \\
\hline
\end{tabular}


The survey of customers has been commonly used to estimate the effects that the programs have had on commuting, and to understand how customers hear about the programs and what services they use. Evaluations of Florida's CAPs in the early 2000's included a phone survey of the working population living in the area served by the CAP. Another phone survey was conducted with CAP's customers. For the purposes of the evaluation, customers are defined as those who have registered with the program to receive ridematching or other services. The first survey assessed public awareness of the CAP, including advertising messages. It also established the mode split of the commuting public in that serviced area.

The proliferation of mobile phones has increased the difficulty and expense of conducting telephone surveys to the point that this was not feasible within the project budget. Over 27 percent of Florida households that have cell phone but no land-line phone service (estimated at 27.1 percent of Florida households in 2009-10) (Blumberg et al., 2011). Cell phone-only households have been found to be less likely than land-line households to respond to telephone surveys and to have different patterns of non-response bias.

There are a range of other conditions that are making telephone surveys increasingly difficult (and costly) to field. For example, more people can screen calls and decline to participate with the prevalence of answering machines (land-line), voice-mail service (standard with cell phones), and caller-ID (both land-line and cell phones). Federal law requires that cell phone numbers be dialed manually rather than with automated equipment. The probability of dialing a phone number that reaches a personal phone also declines with more fax machines, etc. All of these conditions increase the cost of contacting participants.

Two steps were used to help manage the cost of the surveys. The first step was to determine the sample size based on a confidence interval and margin of error acceptable to the decision maker. The second step involved using a sequential mixed mode online/telephone survey to reduce the amount of data collected via a telephone survey.

The public survey was set at 309 individuals per program in the current evaluation. This would allow detecting a 10-percentage-point difference in the percentage of respondents in different service areas, with a $90 \%$ confidence interval, for a sampling error of 5 percent. These criteria apply to values computed from the entire sample; values computed from a portion of the sample (for example, asking just those persons who heard about a ridematching program how they heard about it) would have different difference and confidence criteria.

For the customer-survey (i.e., database), 375 individuals from each program were to be surveyed. This would allow detecting a 10\% difference in average VMT per commuter, with a $90 \%$ confidence interval, for a sampling error of $5 \%$. VMT is the worst case for sampling design because of its large variance at the individual level. The target of 375 responses would allow measurement of smaller differences in other variables and in percentages. 
To help manage the costs of the data collection from six CAPs, a sequential mixed mode survey approach was designed. The data collection contractor would use e-mail to contact those customers who had provided an e-mail address, and ask them to complete the survey using the Internet. In the event that this did not yield enough responses for that particular CAP, data would be collected by telephone. This telephone segment included those who did not respond and those who did not provide e-mail addresses. The general population survey, because there was no way to contact a random subset of the population by e-mail.

This mixed mode survey approach would be of limited use if the CAP does not have e-mail addresses from most of their customers. However, the number of customers who need to be surveyed via the more costly phone survey would be reduced.

The general population survey focused on program awareness but also estimated the extent of paid parking; the length of time that people used commute modes other than driving alone, such as carpooling, or vanpooling; whether they worked compressed workweeks (working the same number of hours in fewer days, thereby allowing the employee to avoid a commute trip every week or two). Other questions were modified to ask when a person's work day begins or ends, rather than when their commute begins; and to improve the quality of information collected about telework. Wording and response categories for several demographic questions were modified to increase consistency with the U.S. Census and thereby facilitate weighting of the results. Finally, the question on type of employer was modified to use categories consistent with the requirements of the TRIMMS ${ }^{\mathrm{TM}}$ model for estimation of the societal benefits.

The survey instrument was modified for administration in each program's service area. Questions asking respondents about their awareness of the ridematching programs were customized to ask about the specific program name, phone number, website, and other program-specific brand information. Each CAP provided as many as three names or brands for use in assessing unaided and aided awareness. The CAPs could also suggest up to three questions that they wanted to ask, beyond the questions that CUTR had already planned. The Districts 4 and 6 program, which has worked with carpooling and tolled express lanes in its service area, asked people whether and why they had used these lanes. The District 3 Tallahassee commuter assistance program in the Tallahassee area, Commuter Services of North Florida, program asked about whether the respondents' employers had been promoting alternative commute modes; the District 7 commuter assistance program, Tampa Bay Area Regional Transportation Authority (TBARTA) program asked aided awareness questions about TMAs with which it partners.

The survey contractor programmed the survey for computer-assisted telephone interviewing (CATI). Following the check of the survey logic and wording, CUTR provided the survey contractor (the Bureau of Economic and Business Research (BEBR) at the University of Florida) with a list of the counties served by each of the six programs. The survey contractor acquired lists of random land-line telephone numbers for each of the program service areas and conducted the survey. The objective was to complete 309 surveys from individuals who were at least 18 years old and working outside the home at least 30 hours per week drawn from the counties served by each program. Where a program does not serve all of the 
counties in an FDOT district, the survey was limited to just those counties served. The original screening criteria were to include people 18 years and older, working at least 35 hours per week, but when the survey was begun in spring 2010, the survey contractor reported much greater difficulty than anticipated in finding eligible respondents. At the time, the unemployment rate in Florida was above 11 percent, with approximately another 8 percent under-employed. In response, CUTR revised the eligibility criterion downward to require at least 30 hours worked per week outside the home.

Depending on which region of the state was being surveyed, it proved necessary to make between 7 and 16 attempts by phone per completed phone survey. Populations served by the two programs in District 3 required the fewest phone numbers per completion; those served by the program in Districts $4 / 6$ required the most, and the survey contractor advised that the Miami-Dade area is one of the most difficult metropolitan areas in the entire U.S. to survey by telephone. For the entire survey, 21 percent of the numbers had been disconnected; another 21 percent reached a phone that never was answered; 14 percent of the numbers reached only an answering machine; another 14 percent reached a household where there was no eligible respondent (at least one person 18 years or older working at least 30 hours a week).

For the customer survey, two portions of the survey were modified for administration to each program's customers:

Questions asking respondents about their awareness of and referral to the ridematching programs were customized to ask about the specific program name, phone number, website, and other program-specific brand information. CUTR requested this information from each program, and allowed each program to submit as many as three names or brands for use in assessing unaided and aided awareness.

Questions asking about use of different program services were customized to match the services that each program actually provides. The most significant changes involved the unaided/aided awareness questions. Because the purpose of these questions is to measure awareness, and secondarily to determine whether it was unaided or aided, CUTR decided that the best way to administer these on the Internet was to replace the open-ended unaided awareness question of the telephone version with a list of services and names provided by each program. The entire list was displayed in random order for each customer, but the three brand names suggested by each program appeared randomly among the first eight on the list. Respondents were instructed to select as many as were appropriate to the question. If they selected one of the three target brands, this was considered unaided awareness, and the survey logic skipped the follow-up aided awareness question. Failure to select one of the three target brands led to the follow-up aided-awareness question for that brand, and recognition of the brand in that follow-up was considered aided response.

CUTR requested and received a copy of the customer contact information from each CAP except for Districts 4 and 6 (South Florida Commuter Services in Miami-Ft. Lauderdale-West Palm Beach area), and provided it to BEBR. South Florida Commuter Services provided its list directly to the contractor. 
To allay concerns about surveying their customers, BEBR and CUTR arranged with the programs to e-mail an invitation to participate in the survey to each customer who had an e-mail address in the customer database. The message was sent under the e-mail address of the program to increase the likelihood of completing the survey. The message contained a unique link for each customer to track who completed the survey and who needed a reminder. These reminder e-mails were sent to nonrespondents one week after the initial invitation, and again a week later. The telephone phase of the survey followed.

Obtaining the quotas proved challenging even with using a mix of e-mails and telephone surveys. 
Table 12 shows the number of persons in each program database in early 2011 when the survey was conducted, the number with e-mail addresses, and the number contacted by phone (many had both e-mail and phone contact information). As expected, some of the CAPs' databases were too small to enable sampling, (given the expected response rate), so it was necessary to contact every customer. The completion rates for the e-mail/Internet survey ranged between 3.1 and 8.7 percent. 
Table 12 - Contacts and Completions for Customer Database Surveys

\begin{tabular}{|c|c|c|c|c|c|c|}
\hline Program & $\begin{array}{l}\text { District } 1 \\
\text { (Sarasota, } \\
\text { Ft. } \\
\text { Myers) }\end{array}$ & $\begin{array}{l}\text { Jackson- } \\
\text { ville }\end{array}$ & $\begin{array}{l}\text { District } 3 \text { - } \\
\text { Pensacola }\end{array}$ & $\begin{array}{l}\text { District } 3 \text { - } \\
\text { Tallahassee }\end{array}$ & $\begin{array}{l}\text { Districts } 4 \\
\text { and } 6 \\
\text { (Miami -Ft. } \\
\text { Lauderdale } \\
\text { - West } \\
\text { Palm B } \\
\text { each }\end{array}$ & $\begin{array}{l}\text { District } \\
7 \\
\text { (Tampa } \\
\text { Bay) }\end{array}$ \\
\hline $\begin{array}{l}\text { Customers in } \\
\text { database }\end{array}$ & 6,647 & 572 & 1,172 & 1,711 & 42,059 & 5,864 \\
\hline E-mails sent & 6,647 & 537 & 167 & 1,351 & N/A & 3,274 \\
\hline $\begin{array}{l}\text { Customers who } \\
\text { clicked on the link } \\
\text { but did not } \\
\text { advance past the } \\
\text { first screen }\end{array}$ & 55 & 2 & 1 & 27 & N/A & 116 \\
\hline $\begin{array}{l}\text { Partially } \\
\text { completed web } \\
\text { surveys }\end{array}$ & 207 & 46 & 11 & 86 & N/A & 284 \\
\hline $\begin{array}{l}\text { Completed web } \\
\text { surveys }\end{array}$ & 229 & 48 & 50 & 39 & N/A & 289 \\
\hline $\begin{array}{l}\text { Number } \\
\text { remaining to be } \\
\text { completed by } \\
\text { phone }\end{array}$ & 146 & 327 & 325 & 336 & 375 & 86 \\
\hline $\begin{array}{l}\text { Completed by } \\
\text { phone }\end{array}$ & 146 & 55 & 65 & 186 & 375 & 86 \\
\hline $\begin{array}{l}\text { Contacted by } \\
\text { phone }\end{array}$ & 1,132 & 491 & 977 & 1,563 & 5,855 & 745 \\
\hline $\begin{array}{l}\text { Attempts by } \\
\text { phone per } \\
\text { completed phone } \\
\text { survey }\end{array}$ & 7.8 & 8.9 & 15.0 & 8.4 & 15.6 & 8.7 \\
\hline $\begin{array}{l}\text { Total complete } \\
\text { (web plus phone) }\end{array}$ & 375 & 103 & 115 & 225 & 375 & 375 \\
\hline
\end{tabular}




\section{CHAPTER 5 - UCARE.TRI MMS SYSTEM AND CONCLUSIONS}

Based on the information collected in previous tasks and the lessons learned from the data collection effort, the preferred system (UCARE.TRIMMS) should:

- Be easy to access

- Be easy to update

- Allow for tailoring to local factors (e.g., emission factors)

- Accommodate various TDM agencies

- Allow for multiple outputs and outcomes with a focus on mode split, emissions, vehicle miles of travel, vehicle trips, and passenger trips

- Provide flexibility for future updates

To address these needs, the decision was made to expand the use of TRIMMS methodologies from a standalone spreadsheet that predicts changes in VMT, etc. to an online system (UCARE.TRIMMS) that uses baseline and current mode split information to calculate a multitude of outputs and outcomes. For more information on TRIMMS' benefit calculation methodologies, the reader is directed to http://trimms.com (Concas and Winters, 2012).

The following screenshots show the UCARE.TRIMMS system at www.ucare.trimms.com

Prior to logging in to UCARE.TRIMMS, a new user is asked to register (Figure 1 ). This feature allows them to add and update their data.

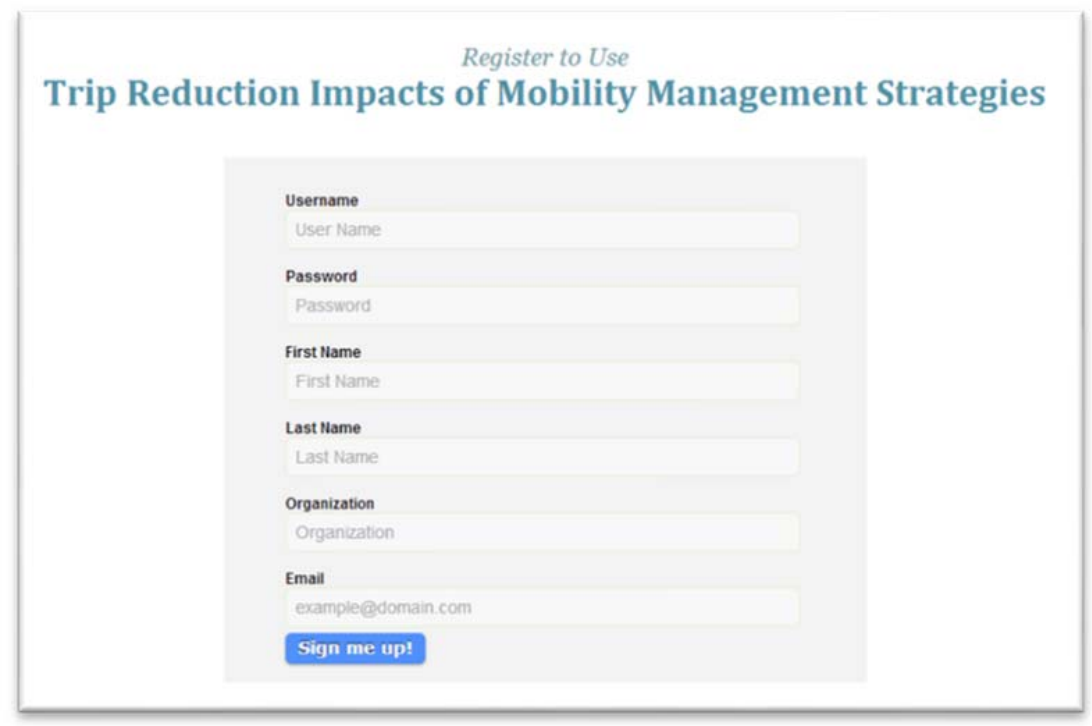

Figure I - UCARE.TRIMMS User Registration 


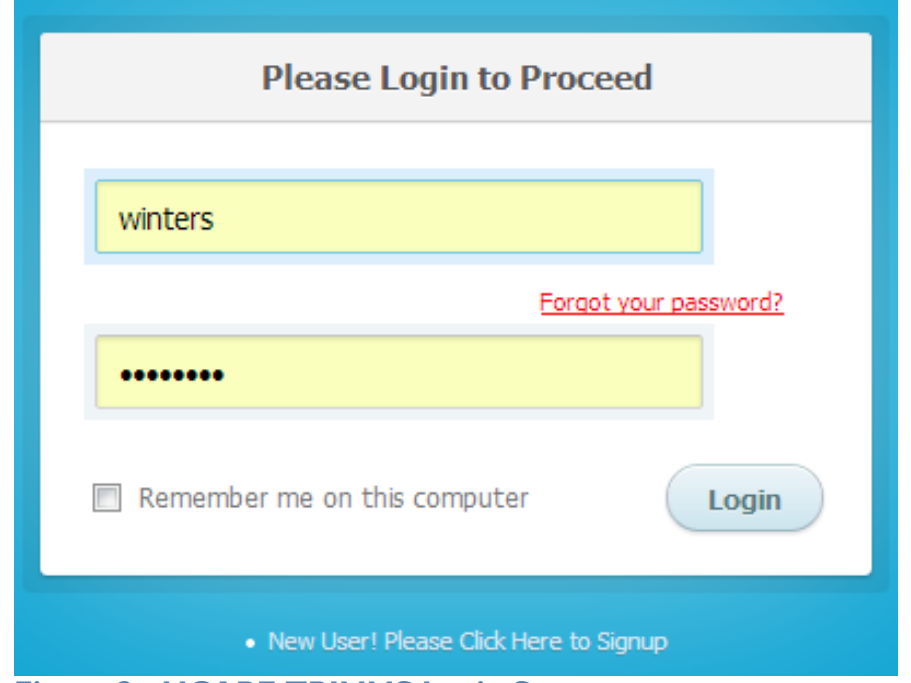

Figure 2 - UCARE.TRIMMS Login Screen

The first screen is where the CAP selects the appropriate urban area or nearest urban area. This selection pulls in the numerous default values such as emission rates, unit costs, etc. It is also where the number of customers is identified. The selection of a 5-day or 7-day work-week provides flexibility if the period of concern is limited to weekdays or not. Finally, the average one-way trip to work is used to help calculate changes.

Intro Employee Survey Before Employee Survey After

Please Select the closest Urban Area

Please enter the number of unique commuters using ridematching services for time period of interest.

Please select work week length.

On average, how many miles is the commuter's one-way trip to work?
Tampa-St. Peters -

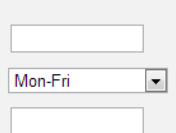

Figure 3 - Program Description 
This screenshot (Figure 4) represents the baseline condition or before situation. Patterned after industry standard methods of tracking mode split over the week, the user enters the number of commuters per day by mode.

\begin{tabular}{l|l|l} 
Intro Employee Survey Before & Employee Survey After
\end{tabular}



Compressed Work Week Day (s) off

$3 / 36$ work week

$4 / 40$ work week

\begin{tabular}{|l|l|l|l|l|l|l|}
\hline 0 & 0 & 0 & 0 & 0 & 0 & 0 \\
\hline
\end{tabular}

$9 / 80$ work week

\begin{tabular}{|l|l|l|l|l|l|l|}
\hline 0 & 0 & 0 & 0 & 125 & 5 & 5 \\
\hline
\end{tabular}

Other Day (s) Off

Vacation

Sick

Regular Day Off, LOA, etc.

Others

Total

\begin{tabular}{l|l|l|l|l|l|}
\hline 0 & 0 & 0 & 36 \\
\hline
\end{tabular}

«Prev Page

Next Page »

Figure 4 - Employee Survey Results - Baseline 
Figure 5 is the screen to result the employee survey results at the end of the period being evaluated.

Intro Employee Survey Before Employee Survey After

Summarize the commute modes of employees for the week of reference After the implementation of the TDM strategies.

Drive Alone

Mon Tue Wed Th Fri Sat Sun

2 persons in vehicle

3 persons in vehicle

4 persons in vehicle

5 persons in vehicle

6 persons in vehicle

7 persons in vehicle

8 persons in vehicle

9 persons in vehicle

10 persons in vehicle

11 persons in vehicle

12 persons in vehicle

13 persons in vehicle

14 persons in vehicle

15 persons in vehicle

Bus

Rail

Motorcycle

Bicycle

Walk

Zero Emission Vehicle (no Hybrids)

Telecommute

Noncommuting

\begin{tabular}{|c|c|c|c|c|c|c|}
\hline 2099 & 2080 & 2049 & 2075 & 1930 & 120 & 125 \\
\hline 222 & 213 & 200 & 204 & 162 & 44 & 39 \\
\hline 45 & 51 & 47 & 50 & 30 & 24 & 24 \\
\hline 4 & 4 & 4 & 4 & 4 & 4 & 4 \\
\hline 0 & 0 & 0 & 0 & 0 & 4 & 4 \\
\hline 0 & 0 & 0 & 0 & 0 & 4 & 0 \\
\hline 91 & 91 & 89 & 88 & 64 & 0 & 4 \\
\hline 0 & 0 & 0 & 0 & 0 & 2 & 2 \\
\hline 0 & 0 & 0 & 0 & 0 & 2 & 2 \\
\hline 0 & 0 & 0 & 0 & 0 & 2 & 2 \\
\hline 0 & 0 & 0 & 0 & 0 & 2 & 2 \\
\hline 0 & 0 & 0 & 0 & 0 & 2 & 2 \\
\hline 0 & 0 & 0 & 0 & 0 & 2 & 2 \\
\hline 0 & 0 & 0 & 0 & 0 & 2 & 2 \\
\hline 0 & 0 & 0 & 0 & 0 & 2 & 2 \\
\hline 176 & 180 & 177 & 180 & 165 & 4 & 4 \\
\hline 0 & 0 & 0 & 0 & 0 & 0 & 0 \\
\hline 6 & 5 & 5 & 5 & 5 & 2 & 2 \\
\hline 65 & 71 & 65 & 58 & 78 & 2 & 2 \\
\hline 28 & 23 & 25 & 25 & 40 & 3 & 3 \\
\hline 0 & 0 & 0 & 0 & 0 & 1 & 1 \\
\hline 159 & 171 & 210 & 179 & 238 & 3 & 3 \\
\hline 0 & 0 & 0 & 0 & 0 & 0 & 0 \\
\hline
\end{tabular}

Compressed Work Week Day (s) Off

$3 / 36$ work week

$4 / 40$ work week

$9 / 80$ work week

\begin{tabular}{|l|l|l|l|l|l|l|}
\hline 0 & 0 & 0 & 0 & 0 & 0 & 0 \\
\hline
\end{tabular}

\begin{tabular}{|l|l|l|l|l|l|l|l|l|}
\hline 0 & 0 & 0 & & 0 & & 115 & 5 & 5 \\
\hline
\end{tabular}

other Day (s) off

Vacation

Sick

Regular Day Off, LOA, etc.

Others

Total

\begin{tabular}{l|l|l|l|}
\hline 0 & 0 \\
\hline
\end{tabular}

«Prev Page

submit

Figure 5 - Employee Survey Results - After 
Figure 6 provides information on the changes in vehicle miles of travel and estimated changes in social costs (dollars per day).

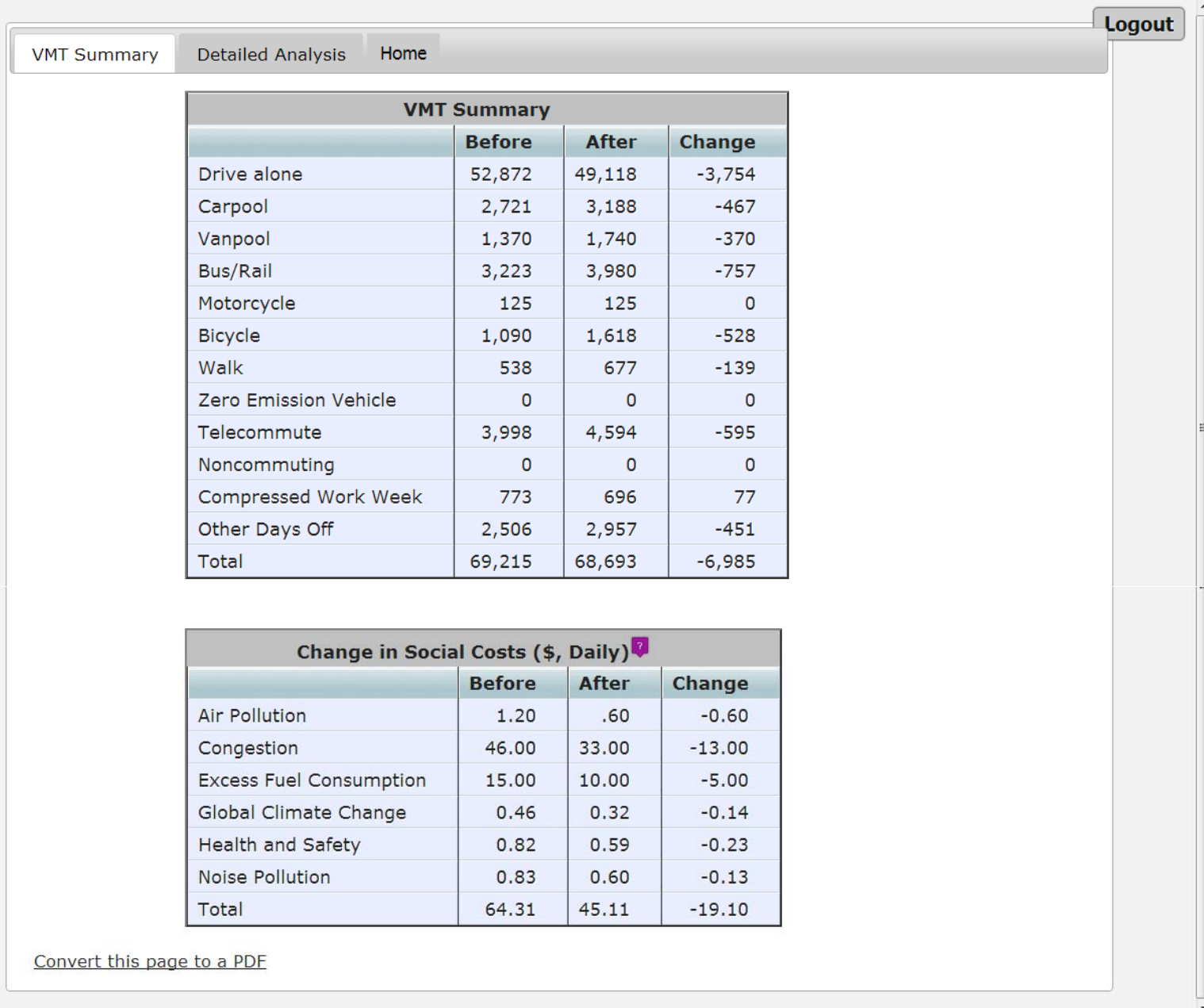

Figure 6 - UCARE.TRIMMS Outcomes 
Figure 8 provides a detailed analysis by emissions in grams per mile, kilograms per day, and changes in associated costs for peak and off-peak periods.

\begin{tabular}{|c|c|c|c|c|c|c|c|c|}
\hline \multirow[t]{2}{*}{ Mode } & \multirow{2}{*}{\begin{tabular}{|c|} 
Rate $(\mathrm{g} / \mathrm{m})$-Peak \\
Default \\
\end{tabular}} & \multirow{2}{*}{\begin{tabular}{|c|} 
Rate $(\mathrm{g} / \mathrm{m})$-Off Peak \\
Default \\
\end{tabular}} & \multicolumn{3}{|c|}{ Change in Emissions (kg/day) } & \multicolumn{3}{|c|}{ Change in Costs ( $\mathbf{S} /$ day) } \\
\hline & & & Peak & Off-Peak & Total & Peak & Off-Peak & Total \\
\hline Ammonia (NH3) & 0.038 & 0.037 & 0.3 & 0.22 & 0.52 & 0.00 & 0.00 & 0.00 \\
\hline Carbon Dioxide Equivalent (CO2_Equiv) & 386.86 & 376.77 & 3036.56 & 2251.88 & 5288.44 & 91.4 & 67.782 & 159.182 \\
\hline Carbon Monoxide (CO) & 2.512 & 2.513 & 19.72 & 15.02 & 34.74 & 0.17 & 0.129 & 0.299 \\
\hline Methane $(\mathrm{CH} 4)$ & 0.005 & 0.005 & 0.04 & 0.03 & 0.07 & 0.00 & 0.00 & 0.00 \\
\hline Nitrous Oxide (N2O) & 0.003 & 0.003 & 0.02 & 0.02 & 0.04 & 0.00 & 0.00 & 0.00 \\
\hline Non-Methane Hydrocarbons (NMHC) & 0.069 & 0.066 & 0.54 & 0.39 & 0.93 & 0.00 & 0.00 & 0.00 \\
\hline Oxides of Nitrogen (NOx) & 0.41 & 0.409 & 3.22 & 2.44 & 5.66 & 3.862 & 2.927 & 6.789 \\
\hline Particulate Matter (PM10) & 0.01 & 0.009 & 0.08 & 0.05 & 0.13 & 0.628 & 0.392 & 1.02 \\
\hline Particulate Matter (PM2.5) & 0.009 & 0.008 & 0.07 & 0.05 & 0.12 & 0.895 & 0.639 & 1.534 \\
\hline Sulfate PM10 & 0.0 & 0.0 & 0.0 & 0.0 & 0.0 & 0.0 & 0.0 & 0.0 \\
\hline
\end{tabular}

Figure 7 - Detailed Emission Results 
Figure 8 - Detailed ResultsFigure 8 provides a view of the "Detailed Analysis" tab that reports estimated changes in vehicle miles of travel by mode.



Figure 8 - Detailed Results 


\section{Conclusions}

UCARE.TRIMMS is the first attempt at a centralized and standardized approach to estimating the most common outputs and outcomes from TDM programs such as changes in emissions, VMT and mode split. UCARE.TRIMMS was built with the understanding that such a system needs to balance ease of use with customization.

Future research could focus on expanding UCARE.TRIMMS to include other services such as Safe Routes to School, shuttle operations, etc. Another area for future investigation would be to assess the life-cycle benefits and costs associated with any of these programs. For example, some of the changes may last more than one year (e.g., average life of a carpool is estimated at $2+$ years).

Finally, the cost of conducting a CAP evaluation will depend on the stated need of a stakeholder as to accuracy and precision for guiding decisions about the CAP. Accuracy accounts for our ability to measure the desired changes (e.g., VMT reductions); precision speaks to the need to be able to reproduce the same results (e.g., sample sizes). These criteria may be set by program managers or outside agencies (e.g., funders) and may relate to the use of the results (e.g., improving performance versus funding decisions). These decisions by stakeholders also have to be made such that the evaluation requirements are a proportional response to the investment in the programs themselves.

Regardless of the outcomes reported, there will be other outputs and outcomes that provide context for differences within and among CAPs. We recognize that not everything that can be counted counts and not everything that counts can be counted. 


\section{References}

Arthur Andersen \& Co. 1972. Project FARE Task I Report: Urban Mass Transportation Industry Information Requirements. Financial Accounting and Reporting Elements (FARE) Project. UMTA-IT-06-0034. DOT-UT-20008. Washington, D.C. July.

Association for Commuter Transportation. 2012. TDM Review: Metrics and Measures, Winter issue. Washington, D.C. p26-32

Blumberg, S. J., Luke, J. V., N. Ganesh, P.M. Davern, M.H. Boudreaux, \& K. Soderberg, (2011, April 20). Wireless Substitution: State-Level Estimates from the National Health Interview Survey, J anuary 2007-J une 2010. Retrieved May 12, 2012, from National Health Statistics Reports: http://www.cdc.gov/nchs/data/nhsr/nhsr039.pdf

Center for Transportation and the Environment, LDA Consulting, and ICI Research, Inc. 2010. Evaluation of Triangle J Transportation Demand Management Programs FY 2009, Final Report. Atlanta, GA: July.

Chu, Xuehao. 2008. Development of a NTD Tool for Vanpool Services, Final Report. Tampa, FL: Center for Urban Transportation Research, University of South Florida. November.

Concas, Sisinnio, Ph.D., and Philip L. Winters. 2012. Estimating Costs and Benefits of Emissions Reduction Strategies for Transit by Extending the TRIMMS Model. BDK85 977-27. Tampa, FL: Center for Urban Transportation Research, University of South Florida. January.

CUTR. 2008. Florida Commuter Assistance Program-Performance Measures. Tampa, FL: Center for Urban Transportation Research, University of South Florida.

Elefteriadou, Lily, Sivaramakrishnan Srinivasan, Ruth L. Steiner, Patricia C. Tice, and Kwangkyun Lim. 2012. Expanded Transportation Performance Measures to Supplement Level of Service (LOS) for Growth Management and Transportation Impact Analysis. Gainesville, FL: Transportation Research Center, The University of Florida. October 31.

FDOT (Florida Department of Transportation). 2002. Commuter Assistance Program. Commuter Assistance Program Procedure Topic No. 725-030-008-g. Public Transit Office. Tallahassee, FL: Florida Department of Transportation. September 24.

Gan, Albert. 2010. Integrated National Transit Database Analysis System (INTDAS), housed within the Florida Transit Information System and developed for Florida Department of Transportation. Lehman Center for Transportation Research, Florida International University. http://www.ftis.org/intdas.html Accessed December 18, 2012. 
GAO (General Accounting Office). 2010. Statewide Transportation Planning: Opportunities Exist to Transition to Performance-Based Planning and Federal Oversight. GAO -1177, Report to the Chairman, Committee on Transportation and Infrastructure, House of Representatives. Washington, D. C. December.

Grant, M., B. Bowen, M. Day, R. Winick, J. Bauer, A. Chavis, et al. (2011). Congestion Management Process: A Guidebook. Washington, DC: United States Department of Transportation - Federal Highway Administration

Gray, Emily. 2012. "Measuring the Short and the Long-Term Effects of the CFC Program," TDM Review, Association for Commuter Transportation, Winter issue. pp. 13-16.

Harvey, David L., J ohn W. Nagel, and William T. Van Lieshout. 1972. Project FARE Task II Report: Urban Mass Transit Industry Reporting Capability. Financial Accounting and Reporting Elements (FARE) Project. UMTA-IT-06-0034. DOT-UT-20008. Washington, D.C.: Arthur Andersen \& Co., November.

Harvey, David L., John W. Nagel, and William T. Van Lieshout. 1973. Project FARE Task II Report: Urban Mass Transit Industry Reporting System Design. Financial Accounting and Reporting Elements (FARE) Project. UMTA-IT-06-0034. DOT-UT-20008. Washington, D.C.: Arthur Andersen \& Co., July.

Hillsman, Edward L., and Philip L. Winters. 2012. Commuter Assistance Program Evaluation (Florida Department of Transportation Research Project BDK84 943-34). Tampa, FL: Center for Urban Transportation Research, University of South Florida. October.

HNTB. (2012). Integrating Transportation Demand Management into the Planning Development Process - A Reference for Cities. San Diego, CA: San Diego Association of Governments.

ICF International. (2011). Potential Changes in Emissions Due to Improvements in Travel Efficiency. Washington, DC: Transportation and Regional Programs Division, Office of Transportation and Air Quality, U.S. Environmental Protection Agency.

Jennings, Howard. 2012. "Research Elevates TDM to the Strategic Level in Arlington County, VA," TDM Review. Association for Commuter Transportation, Winter issue. pp. 9-12.

Killeen, Katie, Natalie Owen and Kevin Luten. 2010. 2009 Transportation Management Association Survey. UrbanTrans. Conducted in association with the TMA Council, Association for Commuter Transportation. March.

Kittelson \& Associates, Inc., Urbitran, Inc., LKC Consulting Services, Inc., MORPACE International, Inc., Queensland University of Technology, and Yuko Nakanishi. 2003. TCRP Report 88: A Guidebook for Developing a Transit Performance-Measurement System. Washington, D.C.: Transportation Research Board. 
LDA Consulting, CIC Research, Inc., ESTC, and Center for Urban Transportation Research. 2012. Commuter Connections Transportation Demand Management Evaluation Project. Washington, D.C.: Metropolitan Washington Council of Governments. January 17.

LDA Consulting, Eric N. Schreffler, Transportation Consultant, and CIC Research, Inc. 2010. Transportation Emission Reduction Measures (TERMs) Revised Evaluation Framework 2008-2011. Washington, D.C.: National Capital Region Transportation Planning Board and Metropolitan Washington Council of Governments. May 18.

MassRIDES. 2010. Monthly Status Reports. Boston, MA: MassDOT. July-September.

Ryus, Paul, Kathryn Coffel, Jamie Parks, Victoria Perk, Linda Cherrington, Jeffrey Arndt, Yuko Nakanishi, and Albert Gan. 2010. TCRP Report 141: A Methodology for Performance Measurement and Peer Comparison in the Public Transportation Industry. Washington, D.C.: Transportation Research Board.

Sallman, D., E. Flanigan, K. Jenanotte, C. Hedden, and D. Morallos. (2012). Operations Benefit/Cost Analysis Desk Reference. Washington, DC: United States Department of Transportation.

Tourangeau, R. (2004). Survey Research and Societal Change. Retrieved May 15, 2012, from Annual Review of Psychology, Vo. 55, pp. 775-801:

http:// www. annualreviews.org/doi/pdf/10.1146/annurev.psych.55.090902.142040

Transit for Livable Communities, Minnesota Center for Environmental Advocacy, and the Surface Transportation Policy Partnership. 2008. Transportation Performance in the Twin Cities Region. August 1.

University of Newcastle upon Tyne, ASM Brescia SpA, Universität für Bodenkultur, Erasmus University, European Transport and Telematics Systems, and Viatek, Ltd. 2000a. EQUIP Part II: The Indicators: Guide to Completion of the Handbook. Brussels, Belgium: European Commission Directorate-General for Energy and Transport.

University of Newcastle upon Tyne, Viatek, Ltd., ASM Brescia SpA, Universität für Bodenkultur, European Transport and Telematics Systems, and Erasmus University. 2000b. EQUIP Summary Report. Brussels, Belgium: European Commission Directorate-General for Energy and Transport.

Westgroup Marketing Research, Inc. 2009. 2009 TDM Annual Survey. Valley Metro, Maricopa Council of Governments, and Maricopa County. 


\section{Appendix - Database Survey I nstrument}




\section{Appendix A: Florida Commuter Assistance Program Evaluation Database Survey Instrument, Districts 4 and 6}

December 9, 2010

Items highlighted in gray will vary with the Commuter Assistance Program (CAP) database being sampled, and some of these items will need to be developed in consultation with staff of the CAP and the FDOT region in which it operates, after funding for the research project is in hand. PI will submit complete modifications of the Database Survey for each CAP to the IRB, and obtain IRB approval, before administering the different versions of the survey to samples drawn from the various CAP service databases.

This version will be administered to a random sample of customers of South Florida Commuter Services, which serves Dade, Broward, Palm Beach, Martin, and St. Lucie counties, although some persons in the sample may live outside these counties. Items in italics may change in other regions

Survey Roadmap

1-2 screen and basic commute data

3-8 awareness

9-12 confirm contact was made

13 use and satisfaction with ridesharing

14-21 pre-service commute

22-23 receipt and use of service

24-53a changes and current commute

53-58a impact and satisfaction

58-62 employer commute benefits/other support

D0-D10 demographics 


\title{
Database Survey Instrument
}

\author{
INTRODUCTION-WEB SCRIPT
}

The University of South Florida's Center for Urban Transportation Research and the Florida Department of Transportation are currently conducting research, with the help of the University of Florida, regarding commuting and traffic issues in your area of Florida.

All your answers are completely confidential, and you do not have to answer any question you do not wish to answer.

You must be at least 18 years old in order to continue with the survey. The survey will take about 10 minutes.

Click here to indicate that you have read and understand this and are willing to continue with the survey.

(INTRODUCTION-TELEPHONE SCRIPT)

Good morning/afternoon/evening. My name is and I am calling from the University of Florida (on behalf of the University of South Florida's Center for Urban Transportation Research and the Florida Department of Transportation). This evening/today we are conducting a survey on commuting and traffic issues in the South Florida area. May I please speak with ?

(INTERVIEWER: READ AS NECESSARY) We are not attempting to sell you anything. We are only interested in your opinions. No information that you provide will be used in a way that can identify you. Your answers will be kept completely confidential and will be used only together with those of other respondents).

(INTERVIEWER: READ AS NECESSARY) The survey will take about 10 minutes.

(INTERVIEWER: READ TO ALL) Before we begin, I would like to let you know that you don't have to participate in the survey. You don't have to answer any questions you don't want to. The survey will take about 10 minutes. We are not attempting to sell you anything. We are only interested in your opinions. No information that you provide will be used in a way that can identify you. Your answers will be kept completely confidential and will be used only together with those of other respondents). Is now a good time? (ARRANGE CALL BACK)

1. How many days per week do you commute to work? IF 0 TERMINATE

2. And about how far is your commute, one-way, in miles?

2a. How many minutes does your commute usually take?

2b. What time do you usually start work? am/pm (WEB VERSION USES DROP-DOWN BOX WITH HALFHOUR INCREMENTS AND ADDITIONAL INSTRUCTION: "Please select the time that comes closest to the time you start work.")

2c. And what time do you usually finish working? am/pm (WEB VERSION USES DROP-DOWN BOX WITH HALF-HOUR INCREMENTS AND ADDITIONAL INSTRUCTION: "Please select the time that comes closest to the time you finish work.") 
3 Are you aware of any organizations that promote carpooling or vanpooling or make it easier for commuters to carpool or vanpool?

Yes

No

Don't know

Refused
01 CONTINUE TO Q.4

02 SKIP TO Q.5

97 SKIP TO Q.5

98 SKIP TO Q.5 
4. Which organizations have you heard of? (IN PHONE VERSION, INTERVIEWER: DO NOT READ LIST; PROBE: ANY OTHERS? IN WEB VERSION, SHOW LIST WITH “NOTE: Please select all that apply.") (MULTIPLE RESPONSES)

$\begin{array}{lll} & & \\ \text { South Florida Commuter Services } & 01 & \\ \text { 1-800-234-Ride } & 02 & \\ \text { www.1800234ride.com } & 03 & \\ \text { Florida/the Department of Transportation } & 04 & \\ \text { Broward County Transit } & 05 & \\ \text { Miami-Dade Transit } & 06 & \\ \text { PalmTran } & 07 & \\ \text { Tri-Rail } & 08 & \\ \text { SunTrolley } & 09 & \\ \text { Downtown Fort Lauderdale TMA } & 10 & \\ \text { South Florida Education Center TMA } & 11 & \\ \text { City of Boca Raton TMI } & 12 & \\ \text { City of West Palm Beach TMI } & 13 & \\ \text { South Florida Vanpools } & 14 & \\ \text { VPSI } & 15 & \\ \text { 95 Express } & 16 & \\ \text { SunPass } & 17 & \text { (WEB ONLY) } \\ \text { None of the above } & 18 & \text { (PHONE ONLY) } \\ \text { Don't know } & 19 & \\ \text { Refused } & 20 & \text { (PHONE ONLY) } \\ \text { Other (specify) } & 99 & \\ & \end{array}$

IF CODE 01 MENTIONED IN Q.4 THEN SKIP Q.5

5. Have you ever heard of South Florida Commuter Services?

$\begin{array}{ll}\text { Yes } & 01 \\ \text { No } & 02 \\ \text { Don't Know } & 97 \\ \text { Refused } & 98\end{array}$

IF CODE 02 MENTIONED IN Q.4 THEN SKIP Q.6

6. Have you ever heard of the commuter information number 1-800-234-RIDE?

$\begin{array}{ll}\text { Yes } & 01 \\ \text { No } & 02 \\ \text { Don't Know } & 97 \\ \text { Refused } & 98\end{array}$

\section{IF CODE 03 MENTIONED IN Q.4 THEN SKIP Q.6a}

6a Have you ever heard of the website www.1800234RIDE.com?

$\begin{array}{ll}\text { Yes } & 01 \\ \text { No } & 02 \\ \text { Don't Know } & 97 \\ \text { Refused } & 98\end{array}$


7. How did you hear about South Florida Commuter Services? (INTERNET VERSION: LIST AND ADD “NOTE: Please select all that apply."; TELEPHONE VERSION: DO NOT READ LIST. INTERVIEWER, IF “NEWSPAPER” OR “RADIO" OR “TELEVISION”, PROBE FOR WHETHER THIS WAS A NEWS STORY (CODE 17) OR ADVERTISING (CODE 1-3); IF "SIGN" MENTIONED, PROBE FOR WHETHER THIS WAS A ROAD SIGN INCLUDING VARIABLE MESSAGESIGNS (CODE 7); A SIGN AT A BUS STOP OR ON A BENCH (CODE 9); A SIGN AT A PARK-AND-RIDE LOT (CODE 18); OR SOMEWHERE ELSE (CODE 19) MULTIPLE RESPONSES)

$\begin{array}{ll}\text { a. Newspaper advertisement } & 01\end{array}$

b. Radio advertisement 02

c. Television advertisement 03

d. At work 04

e. In the mail 05

f. On billboards 06

g. On electronic signs along highways 07

h. On other road signs 08

i. Received a phone call 09

j. At bus stop/on a bench 10

k. On the side of buses/vans 11

I. Friends/co-workers/relatives 12

m. Commuter Fair/Special event/transportation day 13

n. Employer 14

o. Telephone book/Yellow Pages 15

p. Internet 16

q. E-mail 17

r. News story 18

S. Sign at park-and-ride lot $\quad 19$

t. Other (SPECIFY_)

u. Don't Know $\quad 97$

v. Refused 98 
8. How did you hear about the commuter information number, 1-800-234-RIDE or the website WwW.1800234RIDE.com? (INTERNET VERSION: LIST; TELEPHONE VERSION: DO NOT READ LIST. INTERVIEWER, IF “NEWSPAPER” OR “RADIO” OR “TELEVISION”, PROBE FOR WHETHER THIS WAS A NEWS STORY (CODE 17) OR ADVERTISING (CODE 1-3); IF "SIGN" MENTIONED, PROBE FOR WHETHER THIS WAS A ROAD SIGN INCLUDING VARIABLE MESSAGESIGNS (CODE 7); A SIGN AT A BUS STOP OR ON A BENCH (CODE 9); A SIGN AT A PARK-AND-RIDE LOT (CODE 18); OR SOMEWHERE ELSE (CODE 19) MULTIPLE RESPONSES) (SAME LIST AS IN Q.7)

a. Newspaper advertisement 01

b. Radio advertisement 02

c. Television advertisement 03

d. At work 04

e. In the mail 05

f. On billboards 06

g. On electronic signs along highways 07

h. On other road signs 08

i. Received a phone call 09

$\begin{array}{ll}\text { j. At bus stop/on a bench } & 10\end{array}$

k. On the side of buses/vans 11

I. Friends/co-workers/relatives 12

m. Commuter Fair/Special event/transportation day 13

n. Employer 14

o. Telephone book/Yellow Pages 15

p. Internet 16

q. E-mail 17

r. News story 18

s. Sign at park-and-ride lot 19

t. Other (SPECIFY:_ ) 20

u. Don't Know 97

v. Refused 98

9. Have you ever contacted South Florida Commuter Services, 1-800-234-RIDE, www.1800234RIDE.com, or any other local group for carpool or vanpool information?

$\begin{array}{lll}\text { Yes } & 01 & \text { CONTINUE TO Q.10 } \\ \text { No } & 02 & \text { SKIP TO Q.11 } \\ \text { Don't Know } & 97 & \text { SKIP TO Q.11 } \\ \text { Refused } & 98 & \text { SKIP TO Q.11 }\end{array}$


10. Whom did you contact? (IN PHONE VERSION, INTERVIEWER: DO NOT READ LIST; PROBE: ANY OTHERS? IN WEB VERSION, SHOW LIST) (MULTIPLE RESPONSES) (SAME AS LIST IN Q.4)

\begin{tabular}{|c|c|c|c|}
\hline South Florida Commuter Services & 01 & \\
\hline 1-800-234-Ride & & \multicolumn{2}{|l|}{02} \\
\hline www. 1800234 ride.com & & \multicolumn{2}{|l|}{03} \\
\hline Florida/the Department of Transportation & 04 & \multirow{2}{*}{\multicolumn{2}{|c|}{05}} \\
\hline Broward County Transit & & & \\
\hline Miami-Dade Transit & & \multicolumn{2}{|l|}{06} \\
\hline PalmTran & & \multicolumn{2}{|l|}{07} \\
\hline Tri-Rail & & \multicolumn{2}{|l|}{08} \\
\hline SunTrolley & & \multicolumn{2}{|l|}{09} \\
\hline Downtown Fort Lauderdale TMA & & \multicolumn{2}{|l|}{10} \\
\hline South Florida Education Center TMA & & \multicolumn{2}{|l|}{11} \\
\hline City of Boca Raton TMI & & \multicolumn{2}{|l|}{12} \\
\hline City of West Palm Beach TMI & & \multicolumn{2}{|l|}{13} \\
\hline South Florida Vanpools & & \multicolumn{2}{|l|}{14} \\
\hline VPSI & & \multicolumn{2}{|l|}{15} \\
\hline 95 Express & & \multicolumn{2}{|l|}{16} \\
\hline SunPass & 17 & \\
\hline None of the above & & 18 & (WEB ONLY) \\
\hline Don't Know & & \multirow{2}{*}{\multicolumn{2}{|c|}{$\begin{array}{l}19 \text { (PHONE ONLY) } \\
\text { (PHONE ONLY) }\end{array}$}} \\
\hline Refused & 20 & & \\
\hline Other (specify) & & \multicolumn{2}{|l|}{99} \\
\hline
\end{tabular}

11. Have you ever signed up or had your name registered with South Florida Commuter Services or some other carpool/vanpool service?

\begin{tabular}{|c|c|c|c|}
\hline Yes & & 01 & CONTINUE TO Q.12 \\
\hline No & & 02 & SKIP TO * INSTRUCTION FOR Q.13a \\
\hline Don't Know & & 97 & SKIP TO * INSTRUCTION FOR Q.13a \\
\hline Refused & 98 & SKI & * INSTRUCTION FOR Q.13a \\
\hline
\end{tabular}

12. Is your name still registered with that service, or is it no longer registered?

$\begin{array}{lll}\text { Yes, still registered } & 01 & \text { SKIP TO * INSTRUCTION FOR Q.13a } \\ \text { No, not registered } & 02 & \text { CONTINUE TO Q.13 } \\ \text { Don't Know } & 97 & \text { SKIP TO * INSTRUCTION FOR Q.13a } \\ \text { Refused } & 98 & \text { SKIP TO * INSTRUCTION FOR Q.13a }\end{array}$

13. Why did you decide to remove your name from that service? (IN PHONE VERSION, INTERVIEWER: DO NOT READ LIST. PROBE: ANY OTHER REASONS?; IN WEB VERSION, DO NOT LIST, USE TEXT BOX FOR RESPONDENT TO PROVIDE ANSWER)

Didn't get any use out of it 01

Already got started in a carpool/vanpool

02

Didn't like carpooling/vanpooling

03

Didn't provide any names for carpooling/vanpooling 04

Only needed for emergencies $\quad 05$

Moved

06

Changed jobs

07

Other reasons (specify) 
Don't know

Refused
97 (PROBE: Are you sure?

Please think about it) 98

* IF Q.9 IS YES OR Q.11 IS YES, THEN CONTINUE. IF Q.9 IS NOT YES AND Q.11 IS NOT YES, THEN TERMINATE.

The next several questions ask about the ride-matching service available on the www.1800234RIDE.COM website.

13a. Have you used the online ridematching service available on www.1800234RIDE.COM to register with South Florida Commuter Services?

$\begin{array}{lll}\text { Yes } & 01 & \text { CONTINUE } \\ \text { No } & 02 & \text { SKIP TO Q.14 } \\ \text { Don't Know } & 97 & \text { SKIP TO Q.14 } \\ \text { Refused } & 98 & \text { SKIP TO Q.14 }\end{array}$

13b. How did you find out about this ride-matching service? (INTERNET VERSION: LIST; TELEPHONE VERSION: DO NOT READ LIST. INTERVIEWER, IF “NEWSPAPER” OR “RADIO” OR “TELEVISION”, PROBE FOR WHETHER THIS WAS A NEWS STORY (CODE 17) OR ADVERTISING (CODE 1-3); IF “SIGN” MENTIONED, PROBE FOR WHETHER THIS WAS A ROAD SIGN INCLUDING VARIABLE MESSAGESIGNS (CODE 7); A SIGN AT A BUS STOP OR ON A BENCH (CODE 9); A SIGN AT A PARK-AND-RIDE LOT (CODE 18); OR SOMEWHERE ELSE (CODE 19) MULTIPLE RESPONSES) (SAME LIST AS IN Q.7)

$\begin{array}{ll}\text { a. Newspaper } & 01 \\ \text { b. Radio } & 02 \\ \text { c. Television } & 03 \\ \text { d. At work } & 04 \\ \text { e. In the mail } & 05 \\ \text { f. On billboards } & 06 \\ \text { g. On electronic signs along highways } & 07 \\ \text { h. On other road signs } & 08 \\ \text { i. Received a phone call } & 09 \\ \text { j. At bus stop/on a bench } & 10 \\ \text { k. On the side of buses/vans } & 11 \\ \text { l. Friends/co-workers/relatives } & 12 \\ \text { m. Commuter Fair/Special event/transportation day } & 13 \\ \text { n. Employer } & 14 \\ \text { o. Telephone book/Yellow Pages } & 15 \\ \text { p. Internet } & 16 \\ \text { q. E-mail } & 17 \\ \text { r. News story } & 18 \\ \text { s. Sign at park-and-ride lot } & 19 \\ \text { t. Other (SPECIFY: } & 20 \\ \text { u. Don't Know } & 97 \\ \text { v. Refused } & 98\end{array}$

For the next few questions, on a scale of 1 to 5, 1 being very difficult and 5 being very easy, please provide a rating for the following questions

$13 \mathrm{c}$ How easy was it to find the ridematching link on the website www.1800234RIDE.com? 
13d. How easy was it to navigate through the ridematching service?

13e. How easy was it to enter your information into the ridematching service?

13f. How easy was it to understand the rideshare information received from the ridematching service?

13g. Have you visited the ridematching web page since your initial registration?

$\begin{array}{lll}\text { Yes } & 01 & \text { CONTINUE TO Q13h } \\ \text { No } & 02 & \text { SKIP TO Q 13i } \\ \text { Don't Know } & 97 & \text { SKIP TO Q.13i } \\ \text { Refused } & 98 & \text { SKIP TO Q 13i }\end{array}$

13h. Why did you re-visit the ridematching service?

$\begin{array}{lll}\text { Update information } & 01 & \\ \text { Check for new matches } & 02 & \\ \text { Don't Know } & 97 & \text { (PHONE ONLY) } \\ \text { Refused } & 98 & \text { (PHONE ONLY) } \\ \text { Other (specify): } & 99 & \end{array}$

13i. On a scale of 1 to 5 , with 1 being poor and 5 being excellent, what is your overall rating for the ridematching service?

13j. What, if anything, should be done to improve the ridematching service (MULTIPLE RESPONSES) [web version add "choose all that apply"?

$\begin{array}{ll}\text { No improvements necessary } & 01 \\ \text { Make the ridematching service easier to find on website } & 02 \\ \text { Make it easier to navigate website } & 03 \\ \text { Simplify questions } & 04 \\ \text { Improve communication of rideshare information provided } & 05 \\ \text { Other (specify): } & 06 \\ \text { Don't Know } & 97 \\ \text { Refused } & 98\end{array}$

13k. Since you initially registered with the ridematching service, have you visited the Commuter Services of South Florida website for reasons other than using the ridematching service?

$\begin{array}{lll}\text { Yes } & 01 & \text { CONTINUE TO Q13L } \\ \text { No } & 02 & \text { SKIP TO Q 14 } \\ \text { Don't Know } & 97 & \text { SKIP TO Q.14 } \\ \text { Refused } & 98 & \text { SKIP TO Q 14 }\end{array}$

13L. What kinds of information were you looking for on the website? (IN PHONE VERSION, INTERVIEWER DO NOT READ LIST; IN WEB VERSION, SHOW LIST) (MULTIPLE RESPONSES)

$\begin{array}{ll}\text { Emergency Ride Home } & 01 \\ \text { How to get to work without driving } & 02 \\ \text { Telecommuting/telework/working from home } & 03 \\ \text { Bus/Transit schedules or fares or routes or links } & 04 \\ \text { Information on walking/bicycling } & 05 \\ \text { Bike buddy or bike mentor } & 06\end{array}$


$\begin{array}{ll}\text { Park-and-ride lots } & 07\end{array}$

Current traffic conditions/congestion 08

Contests or promotions or prizes or rewards or events $\quad 09$

Commute calendar or record how got to work 10

Other (specify) $\quad 11$

Don't remember/don't recall 97

$\begin{array}{ll}\text { Refused } & 98\end{array}$

$13 \mathrm{~m}$. On a scale of 1 to 5,1 being very difficult and 5 being very easy, how easy was it for you to find the information you were looking for on the Commuter Services of South Florida website?

For the next few questions, I'm going to ask you about how you commuted before you received information from the agency.

14. Before you received the information from the agency, were you driving to work alone every day you worked?

\begin{tabular}{|c|c|c|c|}
\hline Yes & & 01 & SKIP TO Q.14a \\
\hline No & & 02 & CONTINUE WITH Q.14x \\
\hline Don't Know & & 97 & SKIP TO Q.14a \\
\hline Refused & 98 & SK & Q.14a \\
\hline
\end{tabular}

14x. How many days per week were you driving alone to work?

\section{SKIP TO Q15}

14a. When you drove to work, did you ever carpool, that is, go to work with someone else in the car?

\begin{tabular}{|c|c|c|c|}
\hline Yes & & 1 & CONTINUE WITH Q.15 \\
\hline No & & 2 & GO TO Q.21a \\
\hline Don't Know & & 97 & GO TO Q.21a \\
\hline Refused & 98 & \multicolumn{2}{|c|}{ GO TO Q.21a } \\
\hline
\end{tabular}

15. How many days per week were you carpooling to work?

\section{- IF 0, SKIP TO Q.17}

16. About how many people were usually in your carpool, including the driver? - IF 1, SKIP TO Q.17

16a. Just to confirm, was it just you driving, or was it you and another passenger?

$\begin{array}{ll}\text { Just me driving } & 1 \\ \text { Me and another passenger } & 2\end{array}$

17. How many days per week were you vanpooling to work, that is, riding in a van with 7 to 14 other people?

- IF 0, SKIP TO Q.19

18. About how many people were usually in your vanpool, including the driver? (WEB VERSION, ADD: "Note: Please enter a number between 7 and 14"

19. How many days per week were you riding the bus to work? 


\section{IF DISTRICT 4/6, ASK Q.19A, OTHERWISE SKIP TO Q.20.}

19a. How many days per week were you riding the train to work?

20. How many days per week were you getting to work in some other way?

\section{- IF 0, SKIP TO Q.21a}

21. And on those days, how were you getting to work? (SPECIFY:

21a. How many days per week were you telecommuting (that is, working a full day at home during your regularly scheduled work hours, and not traveling to your usual worksite that day)?

$\begin{array}{ll}7 \text { days a week } & 01 \\ 6 \text { days a week } & 02 \mathrm{BEF} \\ 5 \text { days a week } & 03 \\ 4 \text { days a week } & 04 \\ \text { 3 days a week } & 05 \\ \text { 2 days a week } & 06 \\ \text { 1 days a week } & 07 \\ \text { Once every other week } & 08 \\ \text { Once a month } & 09 \\ \text { Once in a while } & 10 \\ \text { Never/not at all } & 11 \\ \text { Don't know } & 97\end{array}$

21b. And were you working a 5-day workweek, or some other kind of work schedule?

5-day workweek 01

Some other schedule

Don't know

Refused
(SKIP TO Q.21d)

02

97 (SKIP TO Q21d)

(SKIP TO Q21d)

21c. Which of the following best describes the schedule you were working, (IF CODE 01 THROUGH CODE 10 IN Q.21a, ADD “counting any telecommuting days as work days?")

5 days a week, 7 or 8 hours a day

4 days a week, 10 hours a day (sometimes called " 4 tens" or " 4 forty")

9 days every two weeks with one day off every other week (sometimes called "9 eighty")

Some other regularly repeating schedule

Irregularly scheduled hours (such as being "on call")

Part time, less than 5 days a week

Other (please describe)

Don't know

Refused
01

02

03

04

05

06

07

97

21d. So, before you received information from the agency, you:

(If q14=1) drove alone to work, without anyone else in the car, every day

(if q14 ne 1) and (if q14x is answered) and (if q14x>0) drove alone to work, without anyone else in the car, (q14x) days per week 
(if q15>0) carpooled (q15) days per week,

(if q17>0) vanpooled (q17) days per week

(if $q 19>0$ ) rode the bus or train (q19) days per week

(if $q 20>0$ ) (q21) (q20) days per week

(if q21a>0) telecommuted (q21a) days per week

Is this correct?
Yes
No 2
CONTINUE TO Q.22
above information in the space below. IN TELEPHONE VERSION, IN TELEPHONE VERSION, INTERVIEWER: INSERT CORRECTIONS AND CONTINUE TO Q.22

In the next few questions, I'm going to ask you about assistance and information provided by the agency.

22. Specifically, what types of assistance or information did the agency or website provide you with? (IN PHONE VERSION, PROBE - DO NOT READ; IN WEB VERSION, LIST, AND ADD: “NOTE: Please select all that apply.") (MULTIPLE RESPONSES)

$\begin{array}{ll}\text { List of potential carpoolers (or "people to go to work with") } & 01 \\ \text { Bus schedules \& routes } & 02 \\ \text { List of potential vanpoolers } & 03 \\ \text { Information about commuter benefits or financial incentives } & 04 \\ \text { Letter stating that no carpool/vanpool matches were found } & 05 \\ \text { Information about Park \& Ride lots } & 06 \\ \text { Information about shuttle services } & 07 \\ \text { Information about Emergency Ride } & \\ \quad \text { Home program } & 08 \\ \text { Tips on what to do next to start carpooling/vanpooling } & 09 \\ \text { Information on 95 Express Registration } & 10 \\ \quad \text { (carpool, vanpool, hybrid) } & 11 \\ \text { Information about telecommuting } & 12 \\ \text { Information about working alternative schedules } & 13 \\ \text { Other (SPECIFY: } & 97 \\ \text { Don't know } & 98 \\ \text { Refused } & \\ \text { (PHONE ONLY) } \\ \text { (PHONE ONLY) } \\ \text { IF Q.22 CODE 08, SKIP TO INSTRUCTION FOR Q.23b. OTHERWISE, ASK Q.23a, }\end{array}$

23a. Did they provide you with information about the Emergency Ride Home program?

$\begin{array}{lll}\text { Yes } & & 01 \\ \text { No } & & 02 \\ \text { Don't Know } & & 97 \\ \text { Refused } & 98 & \end{array}$

\section{IF Q.22 CODE 01 OR Q.22 CODE 03, SKIP TO INSTRUCTION FOR Q.23d. OTHERWISE, ASK Q.23b.}

23b. Did they provide you with a list of potential carpool or vanpool partners?

$\begin{array}{lll}\text { Yes } & 01 & \text { SKIP TO Q.23e } \\ \text { No } & 02\end{array}$


Don't Know

Refused
97

98

IF (Q.22 CODE 05) OR IF (Q.23b IS YES), SKIP TO INSTRUCTION FOR Q.23e. OTHERWISE, ASK Q.23d (note there is no Q.23c-deleted)

23d. Did they send a letter stating that no carpool or vanpool matches were found?

$\begin{array}{ll}\text { Yes } & 01 \\ \text { No } & 02 \\ \text { Don't Know } & 97 \\ \text { Refused } & 98\end{array}$


23e. Thinking about the list of potential carpoolers or vanpoolers you were provided with, did you try to contact anybody on the list?

$\begin{array}{ll}\text { Yes } & 01 \\ \text { No } & 02 \\ \text { Don't Know } & 97 \\ \text { Refused } & 98\end{array}$

IF Q.23e=YES, ASK Q.23f, OTHERWISE SKIP TO Q.24

23f. And did you successfully join a carpool or vanpool with someone from this list?

$\begin{array}{lll}\text { Yes, joined carpool } & 01 & \text { SKIP TO Q.25a } \\ \text { Yes, joined vanpool } & 02 & \text { SKIP TO Q31a INSTRUCTION } \\ \text { No, joined neither } & 03 & \text { CONTINUE } \\ \text { Don't Know } & 97 & \text { CONTINUE } \\ \text { Refused } & 98 & \text { CONTINUE }\end{array}$

24. In the next few questions, I'm going to ask you about how you commuted since you received information from or contacted the agency.

Since you received the information, did you drive to work alone every day you work?

\begin{tabular}{|c|c|c|}
\hline Yes & 01 & CONTINUE \\
\hline No & 02 & SKIP TO Q.24b \\
\hline Don't Know & 97 & SKIP TO Q.24b \\
\hline Refused & 98 & Q.24b \\
\hline
\end{tabular}

24a. When you drove to work, did you ever carpool, that is, go to work with someone else in the car?

\begin{tabular}{|c|c|c|}
\hline Yes & 01 & SKIP TO Q.25 INSTRUCTION \\
\hline No & 02 & SKIP TO Q.32 INSTRUCTION \\
\hline Don't Know & 97 & SKIP TO Q.32 INSTRUCTION \\
\hline Refused & 98 & SKIP TO Q.32 INSTRUCTION \\
\hline
\end{tabular}

24b. Did you ever carpool to or from work after you received the information?

\begin{tabular}{|c|c|c|}
\hline Yes & 01 & CONTINUE \\
\hline No & 02 & SKIP TO Q.31a \\
\hline Don't Know & 97 & SKIP TO Q.31a \\
\hline Refused & 98 & SKIP TO Q.31a \\
\hline
\end{tabular}

ASK Q.25 ONLY IF (EITHER Q.23b IS NOT YES OR Q.23f IS NOT 01) AND (Q.24a IS YES OR Q.24b IS YES). OTHERWISE, SKIP TO Q.25a

25. (PHONE VERSION) And how did you start this carpool?

(INTERVIEWER, IF THE RESPONDENT DOES NOT UNDERSTAND THE QUESTION, PROBE: “DID SOMEONE ASK YOU TO CARPOOL WITH THEM? IF NOT, HOW DID YOU FIND SOMEONE TO CARPOOL WITH?” 
25. (INTERNET VERSIONHow) How did you start this carpool? Did someone ask you to carpool with them? If not, how did you find someone to carpool with? (PROVIDE TEXT BOX FOR RESPONSE)

25a. Are you still carpooling?

$\begin{array}{llll}\text { Yes } & & 01 & \text { CONTINUE } \\ \text { No } & & 02 & \text { SKIP TO Q.29 } \\ \text { Don't Know } & & 97 & \text { SKIP TO Q.29 } \\ \text { Refused } & 98 & & \text { SKIP TO Q.29 }\end{array}$

26. About how many days per week are you carpooling both to and from work?

\section{ASK Q.26A ONLY IF Q.26 < Q1}

26a. And how many days do you carpool only one-way, either to or from work?

27 About how many people are usually in your carpool, including the driver? - IF 0, SKIP TO Q.28

27a. Just to confirm, was it just you driving, or was it you and another passenger?

$\begin{array}{ll}\text { Just me driving } & 1 \\ \text { Me and another passenger } & 2\end{array}$

28. About how long have you been carpooling? (INTERNET VERSION: ADD "Note: Please enter the number of years, months, weeks, and/or days in the spaces below.")

Years Months Weeks Days

\section{SKIP TO INSTRUCTION PRECEDING Q.31a}

29. About how long were you in your carpool?

Years Months Weeks Days

30. How many days per week were you carpooling?

31. About how many people were usually in your carpool, including the driver? IF 0, SKIP TO Q.31a

31aa. Just to confirm, was it just you driving, or was it you and another passenger?

$\begin{array}{ll}\text { Just me driving } & 1 \\ \text { Me and another passenger } & 2\end{array}$

IF Q.26=Q.1 SKIP TO Q.52A

31a. And how many days per week do you drive alone to work now? 
32. Did you ever vanpool to or from work, that is, ride in a van with 7 to 14 other people, after you received the information?

\begin{tabular}{|c|c|c|}
\hline Yes & 01 & CONTINUE \\
\hline No & 02 & SKIP TO Q.40 \\
\hline Don't Know & 97 & SKIP TO Q.40 \\
\hline Refused & 98 & SKIP TO Q.40 \\
\hline
\end{tabular}

33. Are you still vanpooling?

\begin{tabular}{|c|c|c|}
\hline Yes & 01 & \\
\hline No & 02 & SKIP TO Q.37 \\
\hline Don't Know & 97 & SKIP TO Q.37 \\
\hline Refused & 98 & SKIP TO Q.37 \\
\hline
\end{tabular}

34. About how many days per week are you vanpooling both to and from work?

\section{ASK Q.34A ONLY IF Q.34 < Q.1, OTHERWISE SKIP TO Q.35}

34a. And how many days per week are you vanpooling only one-way, either to or from work?

35. About how many people are usually in your vanpool, including the driver?

36. About how long have you been vanpooling? (INTERNET VERSION: ADD "Note: Please enter the number of years, months, weeks, and/or days in the spaces below.")

Years Months Weeks Days

\section{SKIP TO Q.40}

37. About how long were you in your vanpool? (INTERNET VERSION: ADD “Note: Please enter the number of years, months, weeks, and/or days in the spaces below.")

Years Months Weeks Days

38. How many days per week were you vanpooling?

39. About how many people were usually in your vanpool, including the driver?

40. Did you ever ride the bus or train to or from work after you received the information?

$\begin{array}{lll}\text { Yes } & 01 & \text { CONTINUE } \\ \text { No } & 02 & \text { SKIP TO Q.46 } \\ \text { Don't Know } & 97 & \text { SKIP TO Q.46 } \\ \text { Refused } & 98 & \text { SKIP TO Q.46 }\end{array}$

40a. Would that be the bus or the train?

$\begin{array}{ll}\text { Bus } & 01 \\ \text { Train } & 02\end{array}$




\section{USE RESPONSE TO Q40a TO REPLACE “(bus/train)” in Q42-Q45}

41. Are you still riding the (bus/train)?

\begin{tabular}{|c|c|c|}
\hline Yes & 01 & CONTINUE \\
\hline No & 02 & SKIP TO Q.44 \\
\hline t Know & 97 & SKIP TO Q.44 \\
\hline Refused & 98 & SKIP TO Q.44 \\
\hline
\end{tabular}

42. About how many days per week are you riding the (bus/train) both to and from work?

\section{ASK Q.42A ONLY IF Q.42 < Q.1}

42a. And how many days per week are you riding the (bus/train) only one-way, either to or from work?

43. About how long have you been riding the (bus/train)? (INTERNET VERSION: ADD “Note: Please enter the number of years, months, weeks, and/or days in the spaces below.")

Years Months

Weeks Days

\section{SKIP TO Q.46}

44. About how long were you riding the (bus/train) to work? (INTERNET VERSION: ADD “Note: Please enter the number of years, months, weeks, and/or days in the spaces below.")

Years Months

Weeks Days

45. About how many days per week were you riding the (bus/train) to work?

46. Have you used any other way to get to work since you received the information?

\begin{tabular}{|c|c|c|}
\hline Yes & 01 & \\
\hline No & 02 & GO TO Q.52a \\
\hline Don't Know & 97 & GO TO Q.52a \\
\hline Refused & 98 & Q.52a \\
\hline
\end{tabular}

47. And what was that other way of getting to work? (SPECIFY:

48. And are you still getting to work by (INSERT ANSWER TO Q.47)?

\begin{tabular}{|c|c|c|}
\hline Yes & 01 & \\
\hline No & 02 & GO TO Q.51 \\
\hline Don't Know & 97 & GO TO Q.51 \\
\hline Refused & 98 & GO TO Q.51 \\
\hline
\end{tabular}

49. About how many days per week are you (INSERT ANSWER TO Q.47) both to and from work? 
49a. And how many days per week are you (INSERT ANSWER TO Q.47) only one-way, either to or from work?

\section{(ENTER 0 IF QUESTION IS SKIPPED)}

50. About how long have you been (INSERT ANSWER TO Q.47)?

Years Months

Weeks

Days

SKIP TO Q.52a

51. About how long were you getting to work by (INSERT ANSWER TO Q.47)? (INTERNET VERSION: ADD “Note: Please enter the number of years, months, weeks, and/or days in the spaces below.")

Years

Months

Weeks

Days

52. About how many days per week were you getting to work by (INSERT ANSWER TO Q.47)?

52a. Instead of traveling to your usual worksite, did you ever telecommute after you received the information, that is, work a full day from your home during your regularly scheduled work hours and not travel to your usual worksite that day?

\begin{tabular}{|c|c|c|c|}
\hline Yes & & 01 & CONTINUE TO Q.52b \\
\hline No & & 02 & SKIP TO Q.52f \\
\hline Don't know & & 97 & SKIP TO Q.52f \\
\hline Refused & 98 & SKI & Q.52f \\
\hline
\end{tabular}

52b. Are you still telecommuting?

\begin{tabular}{|c|c|c|c|}
\hline Yes & & 01 & \\
\hline No & & 02 & SKIP TO Q.52d \\
\hline Don't know & & 97 & SKIP TO Q.52f \\
\hline Refused & 98 & \multicolumn{2}{|c|}{ SKIP TO Q.52f } \\
\hline
\end{tabular}

52c. How many days per week are you telecommuting instead of traveling to your usual worksite?

$\begin{array}{ll}7 \text { days a week } & 01 \\ 6 \text { days a week } & 02 \\ 5 \text { days a week } & 03 \\ 4 \text { days a week } & 04 \\ 3 \text { days a week } & 05 \\ 2 \text { days a week } & 06 \\ 1 \text { days a week } & 07 \\ \text { Once every other week } & 08 \\ \text { Once a month } & 09 \\ \text { Once in a while } & 10 \\ \text { Never/not at all } & 11 \\ \text { Don't know } & 97 \\ & \end{array}$

SKIP TO Q.52F 
52d. About how long were you telecommuting? (INTERNET VERSION: ADD “Note: Please enter the number of years, months, weeks, and/or days in the spaces below.")

Years Months Weeks Days

52e. How many days per week were you telecommuting instead of traveling to your usual worksite?

$\begin{array}{ll}7 \text { days a week } & 01 \\ 6 \text { days a week } & 02 \\ 5 \text { days a week } & 03 \\ 4 \text { days a week } & 04 \\ 3 \text { days a week } & 05 \\ 2 \text { days a week } & 06 \\ 1 \text { days a week } & 07 \\ \text { Once every other week } & 08 \\ \text { Once a month } & 09 \\ \text { Once in a while } & 10 \\ \text { Never/not at all } & 11 \\ \text { Don't know } & 97\end{array}$

(DO NOT READ) Refused 98

52f. And were you working a 5-day workweek, or some other kind of work schedule?

\begin{tabular}{lrll} 
5-day workweek 01 & (SKIP TO Q.53b) \\
\multicolumn{2}{l}{$\begin{array}{l}\text { Some other schedule } \\
\text { Don't know }\end{array}$} & 02 & (CONTINUE TO Q.52g) \\
(COIP TO Q.53b) \\
Refused
\end{tabular}$\quad \begin{array}{ll}\text { (SKIP TO } \\
\text { (SKIP TO Q.53b) }\end{array}$

52g. Which of the following best describes the schedule you were working, (IF CODE 01 THROUGH CODE 10 IN Q.52e, ADD "counting any telecommuting days as work days?")

$\begin{array}{lr}5 \text { days a week, } 7 \text { or } 8 \text { hours a day } & 01 \\ \begin{array}{l}4 \text { days a week, } 10 \text { hours a day (sometimes called "4 tens" or "4 forty") } \\ 9 \text { days every two weeks with one day off every other week }\end{array} & 02 \\ \quad \text { (sometimes called "9 eighty") } & 03 \\ \text { Some other regularly repeating schedule } & 04 \\ \text { Irregularly scheduled hours (such as being "on call”) } & 05 \\ \text { Part time, less than 5 days a week } & 06 \\ \text { Other (please describe) } & 07 \\ \text { Refused } & 98\end{array}$

53h. Are you still working this schedule?

\begin{tabular}{|c|c|c|c|}
\hline Yes & & 01 & SKIP TO Q53b \\
\hline No & & 02 & SKIP TO Q.52i \\
\hline Don't know & & 97 & SKIP TO Q.53b \\
\hline Refused & 98 & \multicolumn{2}{|c|}{ SKIP TO Q.53b } \\
\hline
\end{tabular}

52i. About how long were you working this schedule? (INTERNET VERSION: ADD “Note: Please enter the number of years, months, weeks, and/or days in the spaces below.")

Years Months Weeks Days 


\section{ASK Q.53b IF Q.24, Q.32, Q.40, Q.46 OR 52a=1 , OR IF (Q31a IS ANSWERED AND Q31a>0, OR IF (Q26 IS ANSWERED AND Q26>0) OR IF (Q.26a IS ANSWERED AND Q.26a>0), OR IF (Q.30 IS ANSWERED AND Q.30>0)); OTHERWISE SKIP TO Q.55}

53b. So, after you received information from the agency, you:

(If (q24=1 or $(q 24 a=2, q 32=2, q 40=2, q 46=2)$ ) drove alone to work, without anyone else in the car, every day

(if q31a is answered and q31a>0) drove alone to work, without anyone else in the car, (q31a) days per week

(if ( $q 23 f=1$ or $q 2 a=1$ or $q 24 b=1$ ) and $q 26>0$ ) carpooled to and from work ( $q 26)$ days per week, (if q26a is answered and q26a>0) carpooled one-way (q26a) days per week

(if ( $q \mathbf{2 3 f}=\mathbf{1}$ or $\mathbf{q 2 4 a = 1}$ or $\mathbf{q 2 4 b = 1}$ ) and $q \mathbf{3 0}>0$ ) carpooled (q30) days per week for (q29)

(if(q23f $=1$ and $q 25 a=1$ and $q 26 a$ is answered and q26a>0) carpooled (q26a) days per week for (q28)

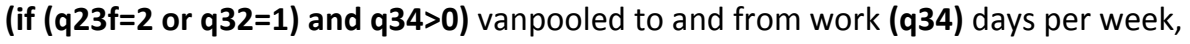

(if $\mathbf{q 3 4 a > 0}$ ) vanpooled one-way (q34a) days per week

(if $q 32=1$ and $q 38>0$ ) vanpooled (q38) days per week for (q37)

(if $q \mathbf{4 0}=\mathbf{1}$ and $q \mathbf{4 2 > 0}$ ) rode the bus (train) to and from work (q42) days per week,

(if $q 42 a>0$ ) rode the bus (train) one-way (q42a) days per week

(if $q 40=1$ and $q 45>0$ ) rode the bus(train) (q45) days per week for (q44)

(if $q 46=1$ and $q 49>0$ ) (q47) to and from work (q49) days per week,

(if $q 49 a>0$ ) (q47) one-way (q49a) days per week

(if $q 46=1$ and $q 52>0$ ) (q47) (q52) days per week for (q51)

If $q \mathbf{5 2} a=\mathbf{1}$ and $\mathbf{q 5 2}>\mathbf{0}$ ) telecommuted (q52c) days per week

If(q52a=1) and $\mathbf{q 5 2 e}>0$ ) telecommuted (52e) days per week for (52d)

Is this correct?

$\begin{array}{lll}\text { Yes } & 1 & \text { CONTINUE TO Q.53 } \\ \text { No } & 2 & \text { (IN WEB VERSION, ADD “Note: Please type in the correction to the }\end{array}$ above information in the space below. IN TELEPHONE VERSION, IN TELEPHONE VERSION, INTERVIEWER: INSERT CORRECTIONS AND CONTINUE TO Q.53

53. To what extent did information or assistance from South Florida Commuter Services influence your choice of how you commute to or from work? Did it have...

A great deal of influence 01

A moderate influence 02

A small influence, or 03

No influence at all $\quad 04$

Don't Know 97

$\begin{array}{lll}\text { (DO NOT READ) } & \text { Refused } & 98\end{array}$ 
54. To what extent did the Emergency Ride Home Program influence your choice of how you commute to or from work? Did it have...



55. And after South Florida Commuter Services provided you with the information, did anyone from that agency follow up with you by letter or phone call to see if you had any further questions or problems?

$\begin{array}{ll}\text { Yes } & 01 \\ \text { No } & 02 \\ \text { Don't Know } & 97 \\ \text { Refused 98 } & \end{array}$

55a. Did you have any further questions or problems with the information?

$\begin{array}{lll}\text { Yes } & 01 & \text { CONTINUE } \\ \text { No } & 02 & \text { SKIP TO Q.56 } \\ \text { Don't Know } & 97 & \text { SKIP TO Q.56 } \\ \text { Refused 98 } & \text { SKIP TO Q.56 }\end{array}$

55b. Did you contact South Florida Commuter Services about them?

$\begin{array}{ll}\text { Yes } & 01 \\ \text { No } & 02 \\ \text { Don't Know } & 97 \\ \text { Refused 98 } & \end{array}$


56. For the next few questions, please respond by using a scale of 1 to 10 , where 1 is the lowest or worst rating and 10 is the highest or best rating. Using this scale, how would you rate the agency on....

(ROTATE LIST)

Worst

Best DK Refused

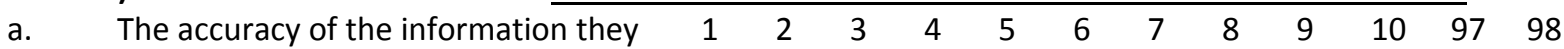
provided

b. The usefulness of the information $\quad \begin{array}{lllllllllllll}1 & 2 & 3 & 4 & 5 & 6 & 7 & 8 & 9 & 10 & 97 & 98\end{array}$ they provided

$\begin{array}{lllllllllllllllll}\text { c. The promptness with which they } & & 1 & 2 & 3 & 4 & 5 & 6 & 7 & 8 & 9 & 10 & 97 & 98\end{array}$ provided the information

d. Their courtesy and professional $\quad \begin{array}{llllllllllllll} & 1 & 2 & 3 & 4 & 5 & 6 & 7 & 8 & 9 & 10 & 97 & 98\end{array}$ attitude

e. $\quad$ Their handling of any questions or $\quad \begin{array}{llllllllllllll}1 & 2 & 3 & 4 & 5 & 6 & 7 & 8 & 9 & 10 & 97 & 98\end{array}$ problems you had

f. The quality and usefulness of the list $\quad \begin{array}{llllllllllllll}1 & 2 & 3 & 4 & 5 & 6 & 7 & 8 & 9 & 10 & 97 & 98\end{array}$ of potential carpoolers or vanpoolers that they sent you

\section{ASK F ONLY IF Q.22-01 OR Q.22-03 MENTIONED OR Q.23B=1}

57. And still using this scale, overall how satisfied are you with this agency's performance?

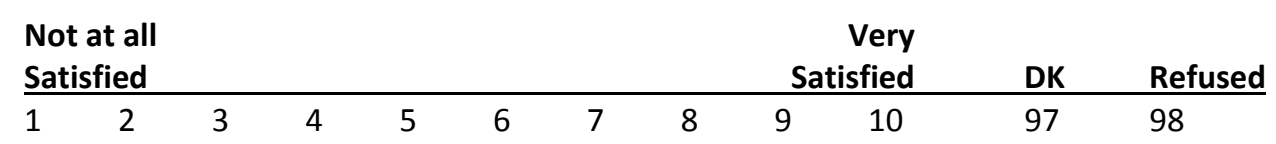

58. And if a friend or relative were to ask you about this carpool/vanpool agency and whether they should use their services, would you....

$\begin{array}{lll}\text { Definitely recommend using this agency } & 05 & \text { GO TO Q.58a } \\ \text { Probably recommend using this agency } & 04 & \text { GO TO Q.58a } \\ \text { Maybe/maybe not recommend them } & 03 & \text { GO TO Q.59 } \\ \text { Probably not recommend them } & 02 & \text { GO TO Q.59 } \\ \text { or definitely not recommend them } & 01 & \text { GO TO Q.59 } \\ \text { Don't know } & 97 & \text { GO TO Q.59 } \\ \text { Refused } & 98 & \text { GO TO Q.59 }\end{array}$

58a. Have you actually recommended South Florida Commuter Services to a friend or relative?

$\begin{array}{ll}\text { Yes } & 01 \\ \text { No } & 02 \\ \text { Don't Know } & 97 \\ \text { Refused 98 } & \end{array}$

59. Does your employer currently offer any type of commuting benefits?

$\begin{array}{lll}\text { Yes } & 01 & \text { CONTINUE TO Q.60 } \\ \text { No } & 02 & \text { SKIP TO INSTRUCTION BEFORE Q.61a } \\ \text { Don't know } & 08 & \text { SKIP TO INSTRUCTION BEFORE Q.61a } \\ \text { Refused } & 09 & \text { SKIP TO INSTRUCTION BEFORE Q.61a }\end{array}$


60. What kind of benefits do they offer? (MULTIPLE RESPONSES)

$\begin{array}{ll}\text { Preferential parking for carpools/vanpools } & 01\end{array}$

Discounted transit or rail passes $\quad 02$

$\begin{array}{ll}\text { Discounted vanpool fares } & 03\end{array}$

Pre-tax payroll deduction for buying transit or rail passes $\quad 04$

Pre-tax payroll deduction for vanpool fares $\quad 05$

Transportation allowance instead of paid parking 06

$\begin{array}{ll}\text { Pre-tax payroll deduction for parking } & 07\end{array}$

Other specify ___ 99

61. What benefit(s) do you currently receive? (MULTIPLE RESPONSES)

$\begin{array}{ll}\text { Preferential parking for carpools/vanpools } & 01\end{array}$

$\begin{array}{ll}\text { Discounted transit or rail passes } & 02\end{array}$

Discounted vanpool fares 03

Pre-tax payroll deduction for buying transit or rail passes $\quad 04$

Pre-tax payroll deduction for vanpool fares 05

Transportation allowance instead of paid parking 06

$\begin{array}{ll}\text { Pre-tax payroll deduction for parking } & 07\end{array}$

$\begin{array}{ll}\text { Not receiving any benefit } & 08\end{array}$

Other specify __ $\quad 99$

\section{IF Q.24=1, OR IF (Q.31A HAS BEEN ANSWERED AND Q31A>0), CONTINUE TO Q.61A. OTHERWISE, SKIP TO} INSTRUCTION * BEFORE Q.61B

61a. (TELEPHONE VERSION) On those days that you drive to work, do you pay to park? (IF RESPONDENT INITIALLY REPLIES “NO”, PROBE: DOES THE RESPONDENT PREPAY PARKING (OR BUY A PARKING STICKER) BY THE WEEK, MONTH OR OTHER PERIOD? DOES THE RESPONDENT'S EMPLOYER DEDUCT A PARKING FEE FROM PAYCHECKS? IF EITHER OF THESE IS “YES" THEN CODE AS “YES").

(WEB VERSION) On those days that you drive to work, do you pay to park? If you pay each day, prepay parking, or purchase a parking sticker, or if your employer deducts a parking fee from your paycheck, please answer "Yes".

$\begin{array}{lll}\text { Yes } & - & 01 \\ \text { No } & - & 02\end{array}$


* IF Q.24A=1 OR Q.24B=1 OR (Q26 IS ANSWERED AND Q26>0) OR (Q26a IS ANSWERED AND Q26a>0), CONTINUE TO ASK Q.61B, OTHERWISE SKIP TO Q61.C

61b. (TELEPHONE VERSION) On those days that you carpool to work, does someone in the carpool pay to park? (IF RESPONDENT INITIALLY REPLIES “NO”, PROBE: DOES THE RESPONDENT OR SOMEONE IN THE CARPOOL PREPAY PARKING (OR BUY A PARKING STICKER) BY THE WEEK, MONTH OR OTHER PERIOD? DOES THE EMPLOYER OF ANY OF THE CARPOOL MEMBERS DEDUCT A PARKING FEE FROM PAYCHECKS? IF EITHER OF THESE IS "YES" THEN CODE AS “YES").

(WEB VERSION) On those days that you carpool to work, does someone in the carpool pay to park? If someone pays each day, prepays parking, or purchases a parking sticker, or if a parking fee is deducted from that person's paycheck, please answer "Yes".

$\begin{array}{ll}\text { Yes } & 01 \\ \text { No } & 02 \\ \text { Don't know } & 03\end{array}$

TELEPHONE VERSION: DO NOT READ. INTERNET VERSION; OMIT

SKIP TO Q.62

61c. (TELEPHONE VERSION) Although you don't drive to work, if you did, would you have to pay to park? (IF RESPONDENT INITIALLY REPLIES “NO”, PROBE: WOULD THE RESPONDENT PREPAY PARKING (OR BUY A PARKING STICKER) BY THE WEEK, MONTH OR OTHER PERIOD? WOULD THE RESPONDENT'S EMPLOYER DEDUCT A PARKING FEE FROM PAYCHECKS? IF EITHER OF THESE IS “YES” THEN CODE AS “YES”).

(WEB VERSION) Although you don't drive to work, if you did, would you have to pay to park? If you would have to pay each day, prepay parking, or purchase a parking sticker, or if your employer would deduct a parking fee from your paycheck, please answer "Yes".

$\begin{array}{ll}\text { Yes } & 01 \\ \text { No } & 02 \\ \text { Don't know } & 03\end{array}$

TELEPHONE VERSION: DO NOT READ. INTERNET VERSION; OMIT

62. (TELEPHONE VERSION) Is there an ETC, Employee Transportation Coordinator, at your worksite? (INTERVIEWER NOTE: AN ETC IS AN EMPLOYEE THAT HELP OTHER EMPLOYEES WITH TRANSPORTATION ISSUES AND SERVES AS THE EMPLOYERS CONTACT PERSON FOR TRANSIT AGENCIES AND/OR COMMUTER ASSISTANCE PROGRAMS)

(WEB VERSION) Is there an employee at your worksite who helps other employees with transportation issues and provides information about transportation options to employees?

$\begin{array}{lll}\begin{array}{l}\text { Yes } \\ \text { No }\end{array} & 01 & \\ \text { Don't Know } & 97 & \begin{array}{l}\text { TELEPHONE VERSION: DO NOT READ. INTERNET VERSION; } \\ \text { OMIT }\end{array} \\ \text { Refused } & 98 & \begin{array}{l}\text { TELEPHONE VERSION: DO NOT READ. INTERNET VERSION; } \\ \text { OMIT }\end{array}\end{array}$


Now I just have a few questions remaining that are for statistical and classification purposes only. Your answers will remain completely anonymous and confidential.

Do. What is your gender?

$\begin{array}{ll}\text { Female } & 1 \\ \text { Male } & 2\end{array}$

D1. What is your marital status?

$\begin{array}{ll}\text { Single } & 1 \\ \text { Married } & 2 \\ \text { Divorced/Separated } & 3 \\ \text { Widowed } & 4 \\ \text { Refused } & 9\end{array}$

TELEPHONE VERSION: DO NOT READ. INTERNET VERSION; OMIT

D2. Do you have any children under the age of 6 in your household?

$\begin{array}{ll}\text { Yes } & 1 \\ \text { No } & 2 \\ \text { Refused } & 9\end{array}$

D3. Do you have any children aged 6-16 in your household?

$\begin{array}{ll}\text { Yes } & 1 \\ \text { No } & 2 \\ \text { Refused } & 9\end{array}$

D4. How many working vehicles do you have in your household?

(RECORD EXACT \#)

D5. What is the highest level of education you have completed? (IN PHONE VERSION, INTERVIEWER DO NOT READ LIST; IN WEB VERSION, SHOW LIST)

$\begin{array}{ll}\text { Did not complete high school } & 1 \\ \text { High school graduate } & 2 \\ \text { Trade/technical school } & 3 \\ \text { Attended college/associate degree } & 4 \\ \text { College graduate } & 5 \\ \text { Post Graduate degree } & 6 \\ \text { Refused } & 9\end{array}$

D6a. Do you have access to the internet at work?

$\begin{array}{ll}\text { Yes } & 1 \\ \text { No } & 2 \\ \text { Refused } & 9\end{array}$

D6b. Do you have access to the internet at home?

Yes 1 


$\begin{array}{ll}\text { No } & 2 \\ \text { Refused } & 9\end{array}$

D6c. What is your key media source in general?

$\begin{array}{ll}\text { Newspaper } & 1 \\ \text { Radio } & 2 \\ \text { Television } & 3 \\ \text { Internet } & 4 \\ \text { Other } & 5 \\ \text { Refused } & 9\end{array}$

D7a. Do you consider yourself to be Latino, Hispanic, or Spanish?

$\begin{array}{lll}\text { Yes } & 01 & \\ \text { No } & 02 & \\ \text { Refused } & 98 & \text { TELEPHONE VERSION: DO NOT READ. } \\ & & \text { INTERNET VERSION; OMIT }\end{array}$

D7b. Which one of the following best describes your racial background. Is it ...

$\begin{array}{lcl}\text { White } & 01 & \\ \text { Black or African-American } & 02 & \\ \text { Asian } & 03 & \\ \text { American Indian or Alaska Native } & 04 & \\ \text { Native Hawaiian or Other Pacific Islander } & 05 & \\ \text { Other, Specify: } & 98 & \\ \text { Refused } & 99 & \text { TELEPHONE VERSION: DO } \\ & & \text { NOT READ. INTERNET } \\ & & \text { VERSION; OMIT }\end{array}$

D8. Please stop me when I read the category that contains your age?

(DO NOT READ) $\quad$ Refused $\quad 9$

$\begin{array}{ll}18-24 \text { years old } & 1 \\ 25-34 & 2 \\ 35-44 & 3 \\ 45-54 & 4 \\ 55-64 & 5 \\ 65 \text { or older } & 6 \\ \text { Refused } & 9\end{array}$

D9. Please stop me when I read the range that contains your household's total income, including yourself and anyone else in your household that worked, for the year 2008 ?

$\begin{array}{ll}\text { Under } \$ 10,000 & \\ \$ 10,000-\$ 14,999 & 02 \\ \$ 15,000-\$ 24,999 & 03 \\ \$ 25,000-\$ 34,999 & 04 \\ \$ 35,000-\$ 49,999 & 05 \\ \$ 50,000-\$ 74,999 & 06 \\ \$ 75,000-\$ 99,999 & 07\end{array}$

01 


$\begin{array}{llcl}\$ 100,000-\$ 149,999 & & 08 & \\ \$ 150,000-\$ 199,999 & & 09 & \\ \begin{array}{l}\$ 200,000 \text { or more } \\ \text { Refused }\end{array} & 10 & 98 & \begin{array}{l}\text { TELEPHONE VERSION: DO NOT READ. } \\ \text { INTERNET VERSION: OMIT }\end{array}\end{array}$

D10. Please stop me when I read the type of employer you work for:

$\begin{array}{lll}\text { Finance, Insurance or Real Estate } & 01 & \\ \text { Manufacturing } & 02 & \\ \text { Retail or Wholesale Trade } & 03 & \\ \text { Transportation, Communications or Utilities } & 04 & \\ \text { Health Services } & 05 & \\ \text { Education } & 06 & \\ \text { Military } & 07 & \\ \text { Government } & 08 & \\ \text { Agriculture, Mining or Construction } & 09 & \\ \text { Information Services } & 10 & \\ \text { Personal Services } & 11 & \\ \text { Other, Specify } & 12 & \\ \text { Refused } & 98 & \text { TELEPHONE VERSION: DO } \\ & & \text { NOT READ. INTERNET } \\ & & \text { VERSION: OMIT }\end{array}$

END: Thank you very much. That concludes our survey. 